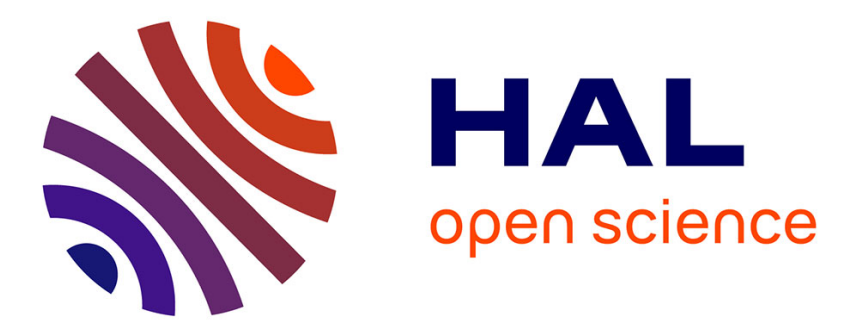

\title{
Dating of the Black Sea Basin: new nannoplankton ages from its inverted margin in the Central Pontides (Turkey)
}

\author{
Jean-Claude Hippolyte, C. Müller, Nuretdin Kaymakci, E. Sangu
}

\section{- To cite this version:}

Jean-Claude Hippolyte, C. Müller, Nuretdin Kaymakci, E. Sangu. Dating of the Black Sea Basin: new nannoplankton ages from its inverted margin in the Central Pontides (Turkey). The Geological Society, London, Special Publications, 2010, 340 (1), pp.113-136. 10.1144/SP340.7 . hal-01961896

\author{
HAL Id: hal-01961896 \\ https://hal.science/hal-01961896
}

Submitted on 7 Nov 2019

HAL is a multi-disciplinary open access archive for the deposit and dissemination of scientific research documents, whether they are published or not. The documents may come from teaching and research institutions in France or abroad, or from public or private research centers.
L'archive ouverte pluridisciplinaire HAL, est destinée au dépôt et à la diffusion de documents scientifiques de niveau recherche, publiés ou non, émanant des établissements d'enseignement et de recherche français ou étrangers, des laboratoires publics ou privés. 
Author version of :

Hippolyte, J-C., Müller C., Kaymakci N. and Sangu E., 2010. Dating of the Black Sea Basin: new nannoplankton ages from its inverted margin in the Central Pontides (Turkey). In: Sosson, M., Kaymakci, N., Stephenson, R. A., Bergerat F., \& Starostenko, V. (eds). Sedimentary Basin Tectonics from the Black Sea and Caucasus to the Arabian Platform. Geological Society, London, Special Publication, 340, 113-136. DOI: 10.1144/SP340.7

\title{
Dating of the Black Sea Basin: new nannoplankton ages from its inverted margin in the Central Pontides (Turkey)
}

\author{
Hippolyte, J-C., Müller C., Kaymakci N. and Sangu E.
}

Jean-Claude Hippolyte : UMR-6635 CNRS - Universite Aix-Marseille III BP 80, Europole Mediterraneen de l'Arbois 13545 Aix en Provence Cedex 4, FRANCE

Carla Müller : IFP, 6 bis rue Haute 92500 Rueil Malmaison

Nuretdın Kaymakci : Middle East Technical University, Department of Geological Engineering, 06531Ankara Turkey.

Ercan Sangu : Kocaeli University, Department of Geological Engineering, 41100 Kocaeli, Turkey

\begin{abstract}
$\underline{\text { Abstract }}$
The Eocene uplift and inversion of a part of the Black Sea margin in the Central Pontides, allows to study the stratigraphic sequence of the Western Black Sea Basin. The revision of this sequence, with 164 nannoplankton ages, indicates that subsidence and rifting started in the Upper Barremian and accelerated during the Aptian. The rifting of the Western Black Sea Basin lasted about 40 Myr (from late Barremian to Coniacian). In the inner, inverted, Black Sea margin, the syn-rift sequence ends up with shallow marine sands. The uppermost Albian to Turonian was a period of erosion or non deposition. This regional midCretaceous stratigraphical gap might result from rift flank uplift, as expected in the case of a thick and cold pre-rift lithosphere. However, coeval collision of the Kargi Block, along the North Tethyan subduction zone at the southern margin of the Pontides, might also have contributed to this uplift. A rapid thermal post-rift subsidence of the margin occurred during the Coniacian-Santonian. Collision of the Kirşehir continental block commenced in Early Eocene time (zone NP12) giving rise to compressional deformation and sedimentation in piggyback basins in the Central Pontides, whereas the eastern Black Sea was still opening.
\end{abstract}

Keywords: Black Sea, Pontides, nannoplankton, Cretaceous, rifting, thermal uplift, inverted margin, piggyback basins 


\section{Introduction}

It is commonly accepted that the Black Sea Basin opened as a back-arc basin during the Mesozoic, as a consequence of the northward subduction of the Neotethys ocean (Hsü et al., 1977; Letouzey et al., 1977; Zonenshain and Le Pichon, 1986) or opened under an extensional regime following the Paleo-Tethyan collision and overthickening of the crust (Yiğitbaş et al., 1999; 2004). However, its precise timing of opening is still under debate (e.g. Nikishin et al., 2003). The Eastern Black Sea Basin is supposed to have rifted in the Upper Palaeocene (Robinson et al., 1995, 1997). This Palaeocene (post-Danian) age of rifting is supported by the presence of an almost complete Mesozoic to Lower Palaeocene series in exploration wells drilled on the Shatsky Ridge (e.g. Robinson et al., 1996). The Western Black Sea Basin is generally considered to have rifted during the Middle Cretaceous (Late Barremian or Aptian-Albian-Cenomanian; e.g. Finetti et al., 1988, Görür, 1988; Manetti et al., 1988; Görür et al., 1993; Robinson et al., 1996). This age is based on facies and thickness variations in the Cretaceous stratigraphic sequence of the Central Pontides (Görür, 1988, 1997, Görür et al., 1993). However, pointing out that arc magmatism started in the Western Pontides only in the Turonian, Tüysüz (1999) then Sunal and Tüysüz (2002) suggested that the main opening phase has occurred during the TuronianMaastrichtian. Moreover, based on heat-flow data, Verzhbitsky et al., (2002) obtained a 70$60 \mathrm{Ma}$ age for the lithosphere of the western and eastern basins.

Surface data concerning the rifting and evolution of the Black Sea can be obtained from the thrust belt of the Pontides, which extends all along its southern margin. The Eocene compression and thrusting have uplifted sediments of the of the Black Sea margin. Therefore, the Cretaceous "synrift" sequence can be precisely dated by onshore studies (Fig. 2). We focused our work in the Central Pontides Belt, where good outcrops of the Mesozoic-Palaeogene sedimentary sequence are present (Görür, 1988; Tüysüz, 1999), while the Eastern Pontides are mainly constituted by an Upper Cretaceous-Oligocene magmatic arc (e.g. Yilmaz et al., 1997). The Central Pontides Belt results from the inversion of part of the southern margin of the Western Black Sea Basin. Thus it may comprise sequences related to the opening of the Western Black Sea Basin, and therefore the oldest syn-rift deposits of the Black Sea.

In order to constrain the timing of the Western Black Sea opening, we have collected 164 samples from the Cretaceous to Palaeogene sedimentary sequences, in 143 localities of the Central Pontides (Table 1). The samples are dated by nannofossils, which provided precise ages for the stratigraphic sequence of the Black Sea margin. The observed main nannofossil assemblages used for each age determination are summarized in Table 2.

\section{Overview of the stratigraphic sequence of the Pontides}

Owing to facies and thickness variations, the Cretaceous sequences of northern Turkey have been divided into a number of formations with local names that causes a great confusion. Görür (1997) has proposed a simplified stratigraphic scheme by distinguishing a "synrift" sequence of Early Cretaceous age, from a "postrift" sequence (Fig. 3).

Lower Cretaceous sediments are generally rare around the Black Sea Basin. They crop out extensively in the Central Pontides (Fig. 2), in particular in the Ulus and the Zonguldak Basins (Fig. 2). It was from stratigraphic studies of these two basins that Görür (1997) proposed that the Çağlayan Group (Fig. 3) represents the syn-rift deposits of the Western Black Sea. This group is a $200 \mathrm{~m}$ to $1300 \mathrm{~m}$ thick sequence of grey to black shales, 
marls and sandstone. Its clastic nature contrasts with the underlying gray to white limestone of the İnalt1 Formation (Derman and Sayıll, 1995) (Fig. 3). According to Görür et al. (1993) and Görür (1997) these sediments, that are rich in organic matter, witness for anoxic conditions resulting from restricted water circulations. They proposed that such anoxic conditions resulted from the disintegration of the carbonate platform by normal fault scarps that isolated the Western Black Sea rift from the main Tethys ocean located to the South. The carbonates of the İnalt 1 Formation are not well dated. Locally foraminifers of Late Oxfordian-Berriasian age were found (Derman and Say1l, 1995). In its stratigraphic log, Görür (1997) considers an Oxfordian-Barremian age for the İnalt Formation and an Aptian to Cenomanian age for the upperlying clastic Çağlayan Formation.

The Çağlayan Formation is overlain, with a slight angular unconformity, by red to pinkish, thinly bedded pelagic limestones, with volcaniclastic intercalations in its upper part. The basal red pelagic limestone form the Kapanboğazı Formation (e.g. Görür et al., 1993) for which an upper Cenomanian to Campanian age was proposed based on foraminifers (Ketin and Gümus, 1963). According to Görür (1997), the drastic change in the style of sedimentation from the dark coloured siliciclastic sediments of the Çağlayan Formations, which accumulated in anoxic condition, to the overlying red pelagic limestones, resulted from a rapid widening of the rift, end of anoxia, and a regional subsidence. This author interprets the Kapanboğazı Formation as a syn-breakup succession.

Tüysüz (1999) however, points out that according to a back-arc basin model, the synrift formation should include evidence of arc magmatism. He proposes that the older unit showing evidence for arc magmatism, the Dereköy Formation (Fig. 3), is the real syn-rift sequence. This formation, is exposed in the Zonguldak Basin, and consists of thick lavas and carbonates of probable Turonian age. It is noteworthy that, if this interpretation is correct, it would mean that the rifting of the Western Black Sea has started in Turonian time, and not as commonly accepted in Aptian time.

Effectively, it is now accepted that no arc magmatism developed in the Pontides during the Lower Cretaceous (Okay et al., 2006). However, volcanic and volcaniclastic rocks are the main elements of the Upper Cretaceous Black Sea margin sequence. The Kapanboğazı Formation conformably passes upwards to the Yemişliçay Formation (Görür, 1997), which is a thick succession (up to $1500 \mathrm{~m}$ ) of volcanic rocks and volcaniclastic sediments with intercalations of red pelagic limestones similar to those of the Kapanboğazı Formation (Fig. 3). Based on foraminifers, a Turonian to Campanian age was assigned to this formation (Aydın et al., 1986, Tüysüz, 1999). The Yemişliçay Formation is overlain by the Akveren Formation of Maastrichtian age (Ketin and Gümüs, 1963). This calciturbidite marks the end of magmatic activity in the Maastrichtian (Tüysüz, 1999; Sunal and Tüysüz, 2002). Its is overlain by the Atbaş1 Formation of Palaeogene age.

\section{Nannoplankton dating of the Pontide stratigraphic sequence}

In the following we present the sedimentary units of the three main areas used in previous studies to establish the general stratigraphic sequence of the Central Pontides (Görür et al., 1993; Görür, 1997; Tüysüz, 1999): the Black Sea coast, the Zonguldak Basin, the Ulus Basin. Nannoplankton age determinations were made to better constrain the age of these units and their correlations. For reasons of simplicity, we follow the tectonostratigraphic schema of Görür (1997) that distinguishes the "syn-rift" Çağlayan Group from the "post-rift" Upper Cretaceous sequences. 


\section{The "syn-rift" Cağlayan Group:}

\section{Black Sea coast}

Along the Black Sea coast, a 0-200 m thick sequence of dark coloured Cretaceous rocks (sandy or clayey limestones) of the Çağlayan Group (Fig. 3), overlays the Upper Jurassic-Lower Cretaceous İnaltı limestones and older rocks. The İnaltı limestone was interpreted as representing the south facing carbonate platform of the Neotethys Ocean (Koçyiğit \& Altıner 2002). The onset of terrigenous sedimentation on the carbonate platform corresponds to a major change that could be related to the opening of the Black Sea rift (Görür, 1988). It is therefore crucial to date the oldest deposits of this group.

Near Zonguldak, Kilimli and Amasra (Fig. 4) the Çağlayan Group is represented by the Kilimli Formation (Tokay, 1952; Görür; 1997) (Fig. 3). It is an alternation of limestone, marls and shales that contains ammonites and nannoplanktons indicating an Aptian age (Tokay, 1952; Akman, 1992). In the Zonguldak area, Tüysüz (1999) also distinguished the lower part of the sequence which includes sandstones, sandy limestone and marls of the Late Barremian-Early Aptian, as the İnpiri Formation. However, as the Kilimli and Inpiri Formations have similar facies and are in the same stratigraphic position, we combined them informally as the Kilimli- Inpiri Formation (Fig. 5).

Nannofossils confirm a Barremian age for the base of the clastic sequence West of Zonguldak (sample 06-4, Fig. 5). Near Amasra, a Barremian age was also determined at the base of the clastic sequence (samples 04-45, 06-43,44,45, 06-49,50,51, fig 6). At Amasra, an Early Aptian age was found in the lower part of the sequence (sample 04-41, Fig. 4) but here most of the Çağlayan sequence have a Late Aptian age (samples 06-40, 06-52, 06-57, 06-58) (Figs. 4 and 6). Similarly, at Kilimli, the samples collected along a $3 \mathrm{~km}$ long new road cut (06-68, 06-72 and 06-73) (Fig. 5) indicate an Early Aptian age, and the samples collected in the upper part of the sequence East of Kilimli (06-64 and 06-66) indicate a Late Aptian age (Fig. 5). It is concluded that along the Black Sea Coast, the Kilimli-İnpiri sequence locally started in the Barremian, but most of the sediments were accumulated during the Late Aptian (Fig. 6). This dating of the first clastic sequence on the platform, together with numerous normal faults observed in the Lower Cretaceous sequence along the Black Sea coast from Zonguldak to Ereğli (Fig. 7), suggest that the rifting and breakup of the carbonate platform (Görür, 1993) started in the Barremian whereas and tectonic activity and subsidence reached its climax during the Aptian.

\section{Zonguldak Basin}

In the Pontides, the best exposures of the Lower Cretaceous sequence are found in the Zonguldak Basin, immediately southeast of the city of Zonguldak (Fig. 5). In this area, the Çağlayan Group was previously studied in detail and subdivided into four formations, the Velibey (Fig. 8), Sapça (Fig. 9), Tasmaca and Cemaller Formation (Fig. 11) (Yergök et al. 1989; Görür, 1997; Tüysüz, 1999; Figs. 3 and 5).

In contrast with the Black Sea coast sections, in most of the northern margin of the Zonguldak Basin, the shelf carbonates of the Inalt1 Formation has been eroded before deposition of the Lower Cretaceous detrital sequence. Yellow-orange sands and well bedded 
sandstones of the Velibey Formation (Fig. 8) rest directly on the Paleozoic sequences (Fig. 5). No nannofossils were encountered in the samples collected from the Velibey Formation to constrain its age of deposition. Likewise no paleontological data have been reported in the previous studies from the sandstones and gravels of this formation (Fig. 8). The sand of the Velibey Formation consists of $95 \%$ quartz. Such an amount of quartz and intense fracturing observed in some outcrops could suggest that some rocks mapped as the Velibey Formation belong to the Pre-Jurassic basement. But its stratigraphic position seems to support an Aptian age. For example, to the Northeast of Zongulgak, the Velibey formation is underlain by the Kilimli Formation and is overlain by the Sapça Formation. To the West of Zonguldak, it overlies the İnalt limestone and it is overlain by the Cemaller Formation (Fig. 5). In addition, Tokay (1952) and Derman (1990) reported the presence of rudists, possibly of Late Albian age, in limestones interbedded in its upper part. It allowed Görür (1997) to propose an Early Albian age for these yellow sands. West of Kizilcakilise (site 06-15, Fig. 5), a new road cut allows observation of what is probably a progressive transition between the shelf carbonates (İnaltı limestone) and the Velibey Formation (Yergök et al., 1989). In this section, white quartz gravels and sandstone layers alternate with dark coal-bearing carbonaceous sandstones. The sample 06-15 collected from this section was barren. However, Late Aptian nannofossils in the samples collected from marls above it (06-11, 0612, Fig. 5) suggest a pre-Late Aptian age for this outcrop of the Velibey Formation (Fig. 6).

The Velibey Formation is overlain by the marine Sapça Formation (Fig. 9), which is similar in aspect with the Kilimli-İnpiri Formation, but more sandy (Fig. 7). It is an alternation of dark colored sandstones with marls or shales rich in organic matter. Its thickness varies from $50 \mathrm{~m}$ to $450 \mathrm{~m}$ and its macro-fauna indicates an Albian age (Fig. 3) (Tokay, 1952; Aydın et al., 1987, Görür et al. 1993). The Tasmaca Formation, another formation of the Çağlayan Group (Fig. 3), is mainly developed near Kızılcakilise (Fig. 5 and 10). This formation is a 100 - to 400 -m-thick succession of poorly bedded organic matter rich black shales and argillaceous limestones similar to those of the Sapça Formation (Figs. 9 and 10). Tokay (1952) proposed that the Tasmaca Formation is of Cenomanian in age, based on ammonite fauna.

However, nannofossil determinations performed in this study allow precise dating of various levels of the Sapça and Tasmaca formations. The samples collected from the Sapça formation are dated Early Aptian (samples 06-78,-81), Late Aptian (samples 06-30, 06-31, 06-75, 06-76, 06-77), and Early Albian (sample 06-32) (Figs. 5 and 6). In contrast with the Cenomanian age of Tokay (1952), the nannofossil samples collected from the Tasmaca Formation indicate Late Aptian (samples 06-11, 06-12), and Early Albian ages (sample 0627, 06-35, 06-36) (Figs. 5 and 6). Therefore Sapça and Tasmaca Formations were contemporaneous during Late Aptian-Early Albian (Fig. 6). We conclude that these formations correspond to local variations in facies and bedding of contemporaneous deposits.

In the South of the Zonguldak Basin, the Tasmaca Formation is overlain by the Cemaller Formation (Fig. 5). This formation is reported on the MTA 1:100 000 geological map (Yergök et al., 1989) but included in the Senonian units on the MTA 1:500 000 geological map (Aksay et al., 2002), and also considered as part of the Upper Cretaceous series by Tüysüz (1999) who describe a "shallow marine Cenomanian clastic sequence". Effectively, the Cemaller Formation does not fit with the deepening character of the basin as indicated by the Sapça and Tasmaca Formations and consists of sands with intercalations of clay and coal (Fig. 11). However, it contains limestone olistoliths similarly to the underlying formations of the Çağlayan Group (Figs. 5 and 9). Moreover, our three samples (06-13, O638, 06-39, Fig. 5) yielded nannoplankton allowing a precise age determination: first part of 
the Upper Albian. On one hand, this age is compatible with the Late Aptian-Early Albian age of the underlying Tasmaca Formation (Figs. 5 and 6). On the other hand, it contrasts with the previously proposed Cenomanian age (Tüysüz, 1999), and therefore invalidates the discontinuity in sedimentation between Cemaller Formation and the underlying formations of the Çağlayan Group. The Middle Cretaceous unconformity noted by Tüysüz (1999) is in fact stratigraphically above the Cemaller Formation.

In the Zonguldak Basin, the Çağlayan Group is overlain by the Dereköy Formation of probable Middle Turonian age (Tüysüz, 1999). Therefore, the Albian and Cenomanian deposits are missing in this basin (Fig. 6). Note that in the Northeast of the Zonguldak Basin, the Cemaller Formation was not deposited or was eroded before the Middle Turonian.

We conclude from these nannoplankton ages that the Velibey, Sapça, Tasmaca and Cemaller Formations of the Zonguldak Basin form a continuous sequence from Late Barremian to the first part of the Late Albian, characterized by non volcanogenic dark clastic material with limestone olistoliths (Fig. 6). Considering that the Çağlayan sequence was interpreted as synrift by Görür (1993) our nannoplankton dating would confirm the Aptian-Albian age of rifting (Fig. 3). However, in contrast with Görür (1993)'s rifting model, the "synrift" sequence does not end up with deep deposits, but with shallow marine sands of the Late Albian Cemaller Formation. Furthermore, in the Zonguldak area, the Middle Cretaceous unconformity corresponds to a major gap in sedimentation (Fig. 3).

\section{Ulus Basin}

The NE-SW trending Ulus Basin is the largest Lower Cretaceous basin of the Pontides (Fig. 2). In contrast to the Zonguldak Basin the Çağlayan Group is described as a single unit: the Ulus Formation (Fig. 3). It starts at the bottom with coarse clastics and grades rapidly into turbiditic sandstones and shales. In the eastern part of the Ulus Basin the flysch deposits are poor in fossils, indicating an Early Cretaceous age (Tüysüz, 1999).

In this study we precisely dated 27 samples from 18 localities in the flysch sequence of the Ulus Basin (Fig. 4). The ages range from Hauterivian near Ağliköy, (Fig. 2, samples 04-12,13, table 1) and Barremian in the center of the basin (samples 04-51, and 06-98 to 06105 ) to Late Aptian (06-90 to 06-95 and 06-106 to 06-108, Fig. 4). These ages are similar to those found along the Black Sea Coast and in the Zonguldak Basin (Fig. 6). Surprisingly the youngest deposits of the Ulus Formation (late Aptian) were found at the base of the sequence on the northwestern edge of the Ulus Basin (Fig. 4; close to the platform carbonates of the İnalt1 Formation). Moreover, the samples 06-106 to 06-108 contain reworked species from the Barremian. This reworking and the onlap of the Çağlayan Formation on the surrounding outcrops of the carbonate basement suggest tectonic activity and tilting during sedimentation, since the Barremian.

In the Ulus basin, the age of the clastic sequence, is older than along the Black Sea coast (Hauterivian at Ağlıköy, Fig. 4). However, the geodynamic significance of the age of onset of detritic sedimentation in this basin is not as clear as along the Black Sea coast. Effectively, in this basin, we could not observe large normal faults like along the Black Sea coast (Fig. 7). Moreover, there are conspicuous compressional structures with intensity of deformation increasing toward the South and the East (Ağliköy area), that is toward the accreted high-pressure-low-temperature complexes of the Early Cretaceous subduction zone (Okay et al., 2006). It is thus possible that, in contrast to the Kilimli-Inpiri Formation, the Ulus flysch was deposited on the accretionary wedge (Fig. 6). Therefore we will not 
consider the age of the Ulus formation as critical for indicating the age of onset of the Black Sea rifting.

Near Ağl1koy, in the East of the Ulus Basin (Fig. 4), black shales of Hauterivian age (samples 04-12, 13) are unconformably overlain by the Kapanboğazı Formation of Santonian age (samples 04-11,15,16, table 1), and the Barremian, Aptian, Albian, Cenomanian, Turonian and Coniacian are missing (Fig. 12). In the Ulus Basin, the youngest sediments of the Ulus Formation are Late Aptian. Similarly to Black Sea coast and the Zonguldak Basin, the Albian, Cenomanian and Turonian deposits are missing in all the Ulus Basin, which reveals a major gap in sedimentation in the Central Pontides (Fig. 6). This gap indicates erosion or non deposition in the mid-Cretaceous. In any case this regional gap was unexpected because according to most of the models (Görür, 1988; Okay et al., 1994; Robinson et al., 1996; Banks and Robinson, 1997), the Western Black Sea Basin was opening at that time (Fig. 3).

\section{Upper Cretaceous-Eocene "post-rift" sequence :}

\section{The Upper Cretaceous volcanic-sedimentary sequence}

In contrast to the Lower Cretaceous Çağlayan sequence, characterized by rapid facies variations, a thick sequence of Upper Cretaceous micritic limestone, volcanogenic and volcanic rocks, overlies the Lower Cretaceous and older rocks in most of the Central Pontides (Fig. 2). The limestone layers are mainly present within the lower part of the sequence and are named as Kapanboğazı Formation (Figs. 3 and 13) (Görür et al. 1993). They are white to pink (hematite rich) micritic and laminated limestones, in decimetric beds with thin clay intercalations (Fig. 14). They contain foraminifers indicative of a pelagic environment (Görür et al., 1993). Volcaniclastic and volcanic rocks intercalations become dominant upwards and the mainly volcanogenic sequence was called Yemişliçay Formation (Görür, 1997) (Fig. 3 and 14).

The 10-50m thick basal "red pelagic limestone" of the Kapanbogazı Formation is present over most of the Central Pontides (Fig. 2). It overlies various older rocks including the Lower Cretaceous and Carboniferous. A few kilometers northeast of Amasra, a new roadcut allows observation of the unconformity of the Upper Cretaceous rocks with the underlying Lower Cretaceous black shales of the Kilimli-Inniri Formation (Yergök et al., 1987) (Fig. 15). It is an angular unconformity of locally up to 50 degrees (Fig. 15). Above the angular unconformity the sequence starts with 5-10 meters of yellowish sands (Cemaller Formation, Yergök et al., 1987), with locally some pebbles at the base. It is characterized by abundant burrows, lamellibranches, gastropods, indicating a shallow marine environment, and pieces of coal probably reworked from the Carboniferous basement outcropping nearby (Fig. 15). Thin sections in the shallow marine sandstones show abundant benthic foraminifers that contrast with the dominantly pelagic foraminifers of the Kapanbogazi red limestone immediately above (Fig. 15). The sharp contact between the sandstones and the pelagic limestones implies a sudden deepening of the Black Sea margin (Tüysüz, 1999).

Samples collected from the Kilimli-İnpiri Formation around Amasra contain nannofossils from Barremian to Late Aptian (Fig. 6). Above the angular unconformity, the sands are of Coniacian-Santonian age (samples 03-12, 04-42, 06-41). They were mapped as the Cemaller Formation (Yergök et al., 1987), however, our new dating indicates that they are much younger than the Late Albian "Cemaller" Formation exposed near Zonguldak. We 
therefore consider that there is no correlation between these sands near Amasra, and the Cemaller Formation exposed near Zonguldak. The Amasra sands belong to the Upper Cretaceous trangressive sequence. In agreement with their Coniacian-Santonian dating, the overlying red pelagic limestone of the Kapanboğazı Formation (named Basköy Formation on the geological map, Yergök et al., 1987) contains nannofossils of Santonian age (samples 03-13, 15) (Fig. 12).

Our nannoplankton ages show that sediments of the Albian, Cenomanian and the Turonian are missing in the Amasra stratigraphic sequence (Fig. 6) confirming the Middle Cretaceous gap mentioned above (Figs. 6 and 12). Moreover, the observation of an angular unconformity at Amasra demonstrates that the gap in the Cretaceous sequence is at least partly due to erosion (Fig. 15). Note that another angular unconformity, with another dip direction in the Kilimli-Inpiri Formation, can be observed between this location and the city of Amasra. The Middle Cretaceous angular unconformity also shows that a tectonic phase occurred before the Coniacian-Santonian transgression. Variations in thickness (hectometers) of the Kilimli-İnpiri Formation around Amasra, and a local hard ground at the base of this clastic sequence indicate that vertical movements occurred during the deposition of these Barremian-Aptian sediments suggesting extensional block faulting at this time.

The Upper Cretaceous section continues with the Kapanboğazı red pelagic limestone. Based on planktonic foraminifers, Görür (1997) dated the Kapanboğazı Formation as Cenomanian to Campanian (Fig. 3). Such a large time span places this formation as a possible lateral equivalent of the Tasmaca and the Yemişliçay Formations. Based on nannofossils studies we could precisely date the red pelagic limestone and the Yemişliçay Formation at several localities. Around Zonguldak, red pelagic limestone are named ìkse Formation of "Turonian-Campanian" age (Yergök et al., 1987) It corresponds to the formation named Unaz in Tüysüz (1999). Northeast of Zonguldak, near Hisarönü (Fig. 13), nannofossils found in this formation indicate a Santonian age (sample 06-63). Near Ereğli (Fig. 13) we also found red pelagic limestones in the ikse Formation, but we could not find characteristic nannoplankton species for a precise age determination (Upper Cretaceous, sample 06-2, table 1). However in this area, we found similar pinkish limestones in the Kale "Turonian-Campanian" formation (Yergök et al., 1987) lying above the Ikse Formation. The nannofossils indicate here also a Santonian age (samples 03-7, 0429, Fig. 13).

These ages are in agreement with the foraminifer dating of Tüysüz (1999) who bracketed the age of the Unaz Formation to the Late Santonian-Campanian (Fig. 3). Considering that our 9 ages of the red pelagic limestone in 5 different localities throughout the Central Pontides (Ereğli, Hisarönü, Amasra, Doganyurt, and Ağliköy, Fig. 13) are the same, we conclude that this limestone is Santonian and therefore does not interfinger with the "synrift" Aptian-Albian Tasmaca Formation (Fig. 3, Görür, 1997). Furthermore, taking into account the angular unconformity described above it is clear that a Lower Cretaceous sedimentary cycle has to be distinguished from an Upper Cretaceous one and that there is a tectonic event occurring in between.

Around Zonguldak, a local formation, comprising clastic, volcanogenic clastic and pyroclastic rocks, is well developed between the Unaz (Kapanboğazi) limestone and the formations of the Çağlayan Group. Tüysüz (1999) named these rocks as the Dereköy Formation (Fig. 3). Yergök et al. (1989) had distinguished in this series four formations, the Cemaller sandstone of Albian-Cenomanian age, the Gökçetepe Formation (lahar and volcaniclastic sands), the Başköy Formation (volcanogenic clastic and marls), and the Dilence Formation (pyroclastics and tuff) of Turonian-Campanian age. Tüysüz (1999) pointed out that the volcanic rocks of the Dereköy Formation represent the onset of arc 
magmatism in the region, which became more active during the Campanian (Cambu Formation) (Fig. 3). Intercalated in this sequence of pyroclastic and andesitic-basaltic lavas, he found pelagic limestone with foraminifers of middle Turonian age. According to this author the upper part of the Cemaller Formation, that he considers as Cenomanian, interfingers with the Middle Turonian pyroclastics and lavas. Therefore he proposes that the Dereköy Formation is Cenomanian-Turonian in age.

However, taking into account our Late Albian nannoplankton dating of the Cemaller Formation near Zonguldak (Fig. 5), and the general gap between the Lower Cretaceous and Upper Cretaceous formations, we cannot follow this interpretation that includes the Cemaller Formation of Zonguldak in the Dereköy Formation and we will not retain this global dating of the Dereköy Formation. Unfortunately, we do not have any new age determination for the Gökçetepe, Basköy and Dilence Formations around Zongudak because they are mainly volcanogenic rocks, and we could not check the middle-Turonian age based on foraminifers for the Dereköy Formation (Tüysüz, 1999). Note however that while near Cide, the Cemaller, Basköy and Dinlence Formations, included in the Dereköy Formation by Tüysüz (1999), contain foraminifers suggesting a Middle-Turonian-Coniacian age for the Dereköy Formation (Tüysüz, 1999), our nannoplankton ages in the same area (Amasra) are more recent, Coniacian-Santonian. Note also that near Amasra, the Basköy and Dilence Formations (Yergök et al., 1987), that form the Dereköy Formation of Tüysüz (1999), correspond on the geological maps to the Kapanboğazı and Yemişliçay Formations of Görür et al. (1993). The age of the Dereköy Formation seems not well constrained. Considering that it corresponds to the lower part of the Yemişliçay Formation of Görür (1997) (Fig. 3), it is possible that it is Santonian, like the rest of the volcanic sequence we dated.

Finally we can precisely date the extent of the regional Mid-Cretaceous stratigraphic gap. Taking into account our lack of ages for the volcanogenic part of the Dereköy Formation near Zonguldak, we conclude that in the Western Pontides, deposits from the uppermost Albian to the lower Turonian are missing. Our sections in the Amasra area (samples 03-12, 04-42, 06-41) and in the Ağliköy area (samples 04-11,15,16) suggest however that this stratigraphic gap may extend from the uppermost Albian to the Coniacian.

The Kapanboğazı red pelagic limestone passes upwards into the Yemişliçay Formation (Görür et al., 1993) equivalent to the Cambu and Dereköy Formations of Tüysüz (1999) (Fig. 3). This formation is an up to $1500 \mathrm{~m}$ thick widespread series of volcaniclastic sediments and volcanic rocks (andesites and basalts) with local intercalations of red pelagic limestones similar to the Kapanboğazı limestones (Ketin and Gümüs, 1963; Görür, 1997) (Fig. 14). It includes the Kazpınar, Liman, Kale and Sarıkorkmaz Formations of Yergök et al. (1989).

Based on foraminifers, a Turonian to Campanian age was proposed for this formation (Aydın et al., 1986, Tüysüz, 1990; Görür et al., 1993) (Fig. 3). However, similar to Kapanboğazı Formation, we have always obtained a Santonian age consistently from several localities in the Central Pontides. For example, at Amasra we dated green and yellow marls intercalated in the lower part of the Yemişliçay volcaniclastic rocks (samples 03-14, 06-42) (Figs. 13 and 14). Near Ereğli, nannofossils found in the calciturbidites of the upper part of the volcanogenic sequence (Kale Formation), confirms this Santonian age (sample 04-30) (Fig. 13). Note that within the volcanogenic sequence, the intercalations of red pelagic limestone also gave a Santonian age at Doğanyurt (sample 03-21), at Ereğli (samples 03-7, 04-29) and at Hisarönü (sample 06-63, Fig. 13). This age is in agreement with our Santonian dating of the underlying Kapanbogazı Formation. Seven kilometers south of Amasra we could date the oldest sediments above the volcanic and volcanogenic sequence of the Yemişliçay Formation. These grey marls named Alaplı Formation and equivalent to 
the Akveren Formation of Görür et al. (1993), contain nannofossils of the lower Campanian (samples 06-59, 60) (Fig. 16). Finally, our nannoplankton dating allows considerably bracketing the age of the Yemişliçay Formation from the Turonian-Coniacian-SantonianCampanian (e.g. Görür, 1997) to the Santonian (Fig. 3). This result is in agreement with the recent age determination by Okay et al. (2006) of a section east of our studied area, near Hanönü, where the basal and upper part of the Yemişliçay Formation contain foramifers characteristic of the Coniacian-Santonian.

\section{The Upper Cretaceous-Tertiary sedimentary formations}

The extensive magmatism ceased after deposition of the Yemişliçay Formation (e.g. Tüysüz, 1999). Whereas Paleocene to Eocene volcanic rocks are well developed in the Eastern Pontides, they are present only locally in the studied area. Sedimentation continues above an unconformity with a $500 \mathrm{~m}$ to $3000 \mathrm{~m}$ thick mainly turbiditic sequence. While in the southern part of the Pontides, the siliciclastic turbidites of the Gürsökü Formation (Ketin and Gümüs, 1963) are generally interpreted as a Maastrichtian forearc flych sequences (Görür et al., 1984; Koçyiğit, 1991; Okay et al., 2006) in the studied area the Akveren, Atbaş1 and Kusuri Formations are distinguished in the Maastrichtian to Eocene sequence (Aydın et al. 1986, Görür, 1997, Tüsüz, 1999, Fig. 3).

The Akveren Formation consists of carbonates and calciturbidites. In the western Pontides, this formation unconformably overlies the older rocks including the Early Cretaceous Ulus Formation. According to Tüysüz (1999) fossils at the base of the Akveren Formation confirm that sedimentation started in a shallow marine environment; then the 10$40 \mathrm{~m}$ thick carbonate mudstone of the Atbaşı Formation denotes a pelagic environment. Akveren and Atbaşı Formations are followed by the 1000-1500 m thick siliciclactic turbidites of the Kusuri Formation.

According to Görür (1997) and Tüysüz (1999), the Akveren calciturbidites are Maastrichtian in age and the Atbaş1 Formation is Palaeocene in age based on foraminifers (Fig. 3). Our nannoplankton dating confirms that the calciturbiditic flysch extends into the upper Maastrichtian (samples 03-9 and 04-20) (Fig. 16). But as mentioned above, nannofossils indicate that the oldest sediments resting on the Yemişliçay volcanogenic formation, the Alapl 1 marls, equivalent to the Akveren Formation, are older: Early Campanian (samples 06-59, 60) (Fig. 16). In the upper part of the Akveren-Alapli Formation we dated thinly bedded limestone of the upper Campanian (samples 04-46, 06-61), thus confirming an age older than estimated before (Görür, 1997; Tüysüz, 1999). We conclude that the Akveren-Alaplı Formation extends from the Lower Campanian to the Upper Maastichtian, which is in agreement with the nannoplankton dating of the underlying Santonian Yemişliçay Formation (Fig. 3).

Near Ağliköy, in the eastern part of the studied area (Fig. 16), we could date of the same age the dark sandstones of the Caylak Formation, (Campanian, sample 03-16 and Early Campanian-Maastichtian, sample 04-4). We infer that this sandstone, that contains echinids, and that onlaps the older formations (Akat et al., 1990), represents a shallow marine facies of the Akveren Formation on the southern margin of the Campanian Black Sea (Fig. 8).

To the East of our mapped area, near Hanönü (Fig. 2), thick sequence of grey marls with 10-20 m white limestone at its base is transgressional on the Yemişliçay - Gürsöku Formations. Okay et al. (2006) recently found nannofossils of the Late Paleocene-Lower Eocene. Our samples gave ages ranging from uppermost Maastrichtian to Middle Eocene 
(uppermost Maastrichtian for samples 06-126 and 06-133 base of the limestone at the entrance of the village of Sirke and East of Hanönü; Late Paleocene NP9, Early Eocene NP13 and Middle Eocene NP14b for samples 06-127, 06-134, and 06-129 respectively, taken from the marls above the basal limestone, table 1). The local presence of uppermost Cretaceous at the base of the transgressional limestone is further confirmed by the finding of an ammonite near Sirke. Considering the timing of the opening of the Black Sea (Robinson et al., 1995), we propose that this transgression on the accretionary wedge is related to the opening of the Eastern Black Sea Basin.

In the Zonguldak-Amasra area, the turbidites reach in age the upper Eocene. The following nannoplankton zones were identified in the Akveren, Atbaşı and Kusuri Formations: Paleocene NP3 (sample 06-19) NP5 (samples 06-18, 20), NP9 (samples 04-22, 06-17,21), Earliest Eocene NP10 (samples 06-22) and NP11 (sample 06-23) (Fig. 16), Early Eocene NP13 (sample 06-25), Middle Eocene NP14b (sample 06-62) and NP15 (samples 06-82), Late Eocene NP19-20 (samples 06-83, Fig. 17). In contrast, in the inner part of the Pontide Belt, the Palaeogene sequence fills intra-mountaineous basins: Karabük Basin, Eflani Basin, Kastamonu Basin, Devrekani Basin (Fig. 17), Boyabat Basin, and Vezirköpru Basin (Fig. 2). Intraformational unconformities at the edge of the basins (Fig. 18) show that they are syn-compressional piggyback basins formed and filled during the construction of the Pontide Belt, similarly to those described in Central Anatolia (Kaymakci 2000). The filling of these intra-mountainous syn-thrusting basins starts in the lower Eocene (zone NP12, e.g. sample 06-121) and ends in the Middle Eocene (zone NP17, e.g. sample 06-125) (Fig. 17). Therefore, even if sedimentation seems continuous in the Zonguldak-Amasra area, on our maps we have distinguished the Palaeocene sequence (Akveren and Atbaş1 Formations, Figs. 3 and 16) from the Early-Eocene Middle-Eocene sediments (Çaycuma and Kusuri Formations, Fig. 3, 17), deposited in a compressional setting. Note that they have a very different geographic distribution, being present in particular inside the Pontide thrust belt (compare figures 16 and 17).

\section{Geodynamical implications}

Dating of the stratigraphic sequence of the Black Sea margin in the Central Pontides allows distinguishing two main periods of deposition: Barremian-Albian, and ConiacianEocene. It reveals a long Mid-Cretaceous period of erosion that contrasts with the classical models of this margin where an Aptian-Albian rifting was immediately followed by rapid Upper Cretaceous thermal subsidence (e.g. Görür et al., 1993).

\section{Barremian to Albian}

The Barremian-Albian sedimentary cycle starts with shallow marine clastic sediments. The Lower Cretaceous black shales and sandstones were interpreted as indicating anoxia during the Black Sea rifting, and were related to the opening of the Black Sea as a back-arc basin (Görur et al. 1993). This argument is not conclusive because anoxic events are frequent worldwide during this period. Besides, as noticed by Tüysüz (1997) the general absence of subduction-related magmatism during the Early Cretaceous does not support this interpretation. However, there are strong evidences that support the synrift interpretation of the Lower Cretaceous sequence. The arrival of detrital material on the carbonate platform denotes a major environmental change. At Amasra, Aptian sediments contain abundant clasts of Carboniferous coal attesting for local uplift and erosion during Lower Cretaceous 
subsidence and sedimentation. We could observe numerous normal faults that control thickness variations in the Lower Cretaceous deposits along the Black Sea coast (Fig. 7). This syntectonic sedimentation is also attested by the presence of olistoliths. Blocks of up to several tens of meters, mostly derived from the Upper Jurassic-Lower Cretaceous Inalt1 limestone, have been found in the Kilimli (Görür, 1997), Sapça (Derman, 1990) and Tasmaca Formations (Siyako et al., 1981). We have also identified a three-hundred-meter long olistolith of Paleozoic limestone within the early Aptian Sapça Formation (Fig. 9). Thickness variations, olistoliths and hard grounds allow dating the rifting from the Barremian to the Albian.

After deposition of hundreds to thousands of meters of sediments, this sedimentary cycle ended up in the upper Albian with sedimentation of shallow marine sands. Nannofossil dating gives evidence for a regional gap ranging from the uppermost Albian to the Turonian/Coniacian. An angular unconformity at Amasra demonstrates that this stratigraphic gap is partly erosional (Figs. 11, 12 and 15). Considering that this erosion follows syn-rift sedimentation and subsidence, we propose that it results from a thermally induced uplift of the rift shoulders. Such rift flank uplift can be expected during rifting of a thick (cold) lithosphere with high mechanical strength and high depth of necking (level of no vertical motions in the absence of isostatic forces; Fig. 19), which was inferred for the Western Black Sea Basin (Robinson et al., 1995; Spadini et al., 1996; Cloetingh et al., 2003).

The onset of rifting was characterized by the break of the carbonate platform and the arrival of clastic deposits (Görür, 1988). This normal faulting of the carbonate platform is evident all along the Black Sea coast between Zonguldak and Amasra (Fig. 2, 6 and 7). This SW-NE ridge was probably a horst during Cretaceous. Okay et al. (2006) have evidenced SW-NE trending units of Cretaceous HP/LT metamorphic rocks to the Southeast (Fig. 2). The Ulus Basin, elongated in the same SW-NE orientation is located between the Zonguldak-Amasra horsts and this Cretaceous accretionary complex. Our dating reveals a diachronous age for the base of this clastic sequence. Clastic sedimentation already existed during Hauterivian in the eastern areas (near Ağlıköy, Figs. 2 and 12) while carbonates deposition continued in the Zonguldak-Amasra horsts to the West. Likewise, compressional deformation of the Ulus Formation grades rapidly toward the Southeast and the accretionary complexes (Fig. 2). Taking into account this SW-NE structural trend and this WNW-ESE evolution of the deformation and sedimentation, we propose that the deep depositional environment of the Ulus flysch and its intense deformation are related to its proximity to the Lower Cretaceous accretionary prism (Fig. 6). In this frame, the Hauterivian age of Ağlıöy might not mean that extension occurred earlier in this area, but that deep marine conditions existed along the active margin (Fig. 6).

\section{Coniacian to Eocene}

Following the Turonian erosion, a new sedimentary cycle starts with ConiacianSantonian shallow marine sands and a thick Santonian volcanic and volcaniclastic sequence with pelagic limestones intercalated. It continues with the deposition of the Akveren-Atbaş1 flysch sequence which onlaps older rocks (Fig. 3). The distribution of the Senonian deposits along the Black Sea and their north-south variations in facies clearly indicate that they are deposits of the Black Sea margin (Fig. 13 and 16). The sharp transition from shallow marine sands to pelagic limestone (fig. 15) indicates a rapid deepening of the margin that is probably related to a post-rift thermally induced subsidence (Görür, 1988). The large thickness of the Senonian-Palaeocene sequence (up to 3000 m, Fig. 3) and its widespread 
distribution, support this post-rift interpretation. Consequently the stratigraphic sequence of the Central Pontides allows precise determination of the age of rifting of the Western Black Sea Basin: from Late Barremian to Coniacian-Santonian time (fig. 3). We conclude that the rifting of the Western Black Sea was very long: 40 Myr.

Compression and uplift occurred from Eocene to Present times. In the Pontides, the Eocene sequence was generally deposited within intra-mountainous basins (Fig. 17). Intraformational angular unconformities (Fig. 18) demonstrate that compression was syndepositional. Therefore, the age of the onset of compression could be accurately determined by dating the older syn-compressional deposits. In the Central Pontides they are of Early Eocene age (nannoplankton zone NP12). We explain the marine sedimentation in the intramountainous piggyback basins by the combined effects of post-rift subsidence of the Black Sea margin and loads of the Pontide thrust piles, in compensating the compressional uplift at its beginning. After the subsidence and filling of the piggyback basins by the end of Middle Eocene (NP 17), compressional deformation continued as shown by the folding of the uppermost Eocene marine sediments. We relate the Eocene onset of compression, to the collision of the Kirşehir continental block, a promontory of the Tauride-Anatolide Block (Fig. 1). This local collision explains the diachronous onset of compression between the Central Pontides (Early Eocene, NP12) and the Greater Caucasus (Late Eocene, e.g. Robinson et al., 1995). The indentation of the Kirşehir Block into the Pontides resulted in the northward convex arc geometry of the Central Pontides (Kaymakci, 2000; Kaymakci et al., 2003a, and b) and the inversion and uplift of part of the southern Black Sea margin whose sequence is now exposed onshore.

\section{$\underline{\text { Discussion }}$}

The Mesozoic-Tertiary stratigraphy of Central Pontides shows that the region experienced two main subsidence phases separated by an uplifted and erosion during the Cretaceous. The significance of these movements needs to be discussed in the frame of the geodynamic evolution of the Black Sea. It is clear that the Lower Cretaceous represents a period of rifting. However, this rifting was not associated with arc volcanism (e.g. Okay et al., 2006) and according to Tüysüz, (1999) could predate a Upper Cretaceous rifting and oceanic spreading contemporaneous of arc volcanism.

Zonenshain and Le Pichon (1986) proposed that the Black Sea results from back arc extension during three successive episodes: 1) Early Middle Jurassic (opening of the Great Caucasus Basin), 2) Late Jurassic-beginning of the Cretaceous (opening of the Pre-Black Sea), and 3) end of the Cretaceous-Early Palaeogene. While the second event didn't lead to complete break up of the basement, the third episode of extension lead to the formation of deep oceanic basins partially closed during the Tertiairy. This model was controversial because during the Neocomian the circum Black Sea region was a shallow shelf (Görür, 1988). However, it considers the possibility of pre-Black Sea rifting episodes.

Accordingly, the Barremian-Albian extensional tectonics (Fig. 7) could be interpreted as a pre-Black Sea rifting that may not have resulted in a complete break-off of the basement. The Ligurian back-arc basin showed such an evolution. Its Provençal margin was cut by NNE-SSW grabens belonging to the Eocene-Oligocene West-European intracontinental rift, and then it was break-off obliquely along the ENE-WSW Late Oligocene Liguro-Provençal back arc rift, that evolved to an oceanic basin (Hippolyte et al., 
1993). A supporting evidence for a similar pre-Black Sea rifting unrelated to subduction, could be that along the Black Sea coast subsidence started in Barremian, before the beginning of convergence of Africa with respect to Europe (before 120-83 Ma, Rosenbaum et al., 2002). Such idea of extensional tectonics unrelated to subduction was already proposed by Yiğitbaş et al. (1999).

However, the age of eclogites in the South of the Pontides, shows that, even though there was no arc magmatism in the Pontides during the Late Jurassic-Early Cretaceous (e.g. Okay et al., 2006), subduction and accretion were acting on the northern margin of the Neotethys Ocean during the Albian. Therefore, the Early Cretaceous subsidence and extensional faulting evidenced along the Black Sea coast (Fig. 7) might be related to this subduction. Moreover, in South Dobrogea and in the Moesian platform (Burchfiel, 1976; Sandulescu, 1978) carbonate deposition was marked by the arrival of abundant terrigenous material during the Aptian-Albian, suggesting that the Barremian-Albian rifting affected the conjugate margins of the Western Black Sea. Furthermore, seismic data show that the Karkinit through, West of Crimea, opened probably during Mid-Cretaceous and has an Upper Cretaceous-Eocene post-rift sequence (Robinson et al., 1996). Finally, paleomagnetic analyses of the Kapanboğazı Formation in the Central Pontides indicates a paleolatitude of $21.5^{\circ} \mathrm{N}$, (Channell et al., 1996) with the implication that the West Black Sea Basin was opened by the Coniacian-Santonian (Okay et al., 2006).

In the frame of the Lower Cretaceous rifting, the Middle Cretaceous erosion of the Pontides region most probably results from a thermal uplift of the rift shoulders. Seismic data offshore Romania and Bulgaria show a regional unconformity in agreement with this thermal doming interpretation (Robinson et al., 1996). However, we cannot exclude that a part of the stratigraphic gap identified was related to the evolution of the subduction zone to the south. Effectively, the recent study of Albian eclogites in the accretionary complex south of the studied area (Okay et al., 2006) shows that an up to $11 \mathrm{~km}$ thick crustal slice (the Domuzdag complex, Ustaömer and Robertson, 1997) of the Tethyan oceanic crust was metamorphosed at HP-LT at 105+/-5 My, and exhumated in Turonian-Coniacian times in a fore-arc setting. This exhumation might be the consequence of the collision of the Karg 1 continental block that occurred just before, along the south facing Tethyan margin of the Pontides (Okay et al., 2006). It is thus possible that this collision participated in uplifting the Central Pontides during the Cenomanian-Turonian. This accretion was followed by the initiation of a new subduction zone to the south (Okay et al., 2006). We infer that this new subduction zone was wider than the Barremian-Albian one that was only related to the opening of the Western Black Sea Basin. Effectively this later might have extended all along the Santonian volcanic arc, which is present in all the Pontides, and was related to the opening of the Eastern Black Sea Basin and the possible reactivation the Western Black Sea Basin. 


\section{Conclusions}

Nannofossil investigations provided accurate ages for the sedimentary units of the Central Pontides. That superposed formations dated independently provide compatible ages, supports the validity of our age determinations.

The rifting of the Western Black Sea Basin, that break up the Upper Jurassic to Lower Cretaceous carbonate platform, started within the Barremian, but the main tectonic activity and subsidence took place during Aptian to Albian times. The synrift sequence (Çağlayan Formation) is a detritic sequence containing olistoliths. It is characterized by rapid variations in facies and thickness, especially across normal faults.

In the inner Black Sea margin, now inverted in the Pontide Belt, sediments of uppermost Albian to Turonian age are missing. This large regional stratigraphic gap, although not clearly identified by means of foraminifers, corresponds to the breakup unconformity of Görür (1997). Although tectonic analysis is necessary to better constrain the origin of the Cretaceous vertical movements, the observation of numerous normal faults in the Early Cretaceous series, and the angular unconformity observed at Amasra, support the idea that erosion occurred during rifting. It is interpreted here as resulting mainly from the thermal uplift of the Western Black Sea rift shoulders.

Age determinations based on nannofossils show that the post-rift subsidence, which was thought to start in Cenomanian time (Görür, 1997), only began in the ConiacianSantonian. The Cretaceous arc-volcanism that was considered to occur during the Turonian to Campanian, is bracketed to the Santonian in the Central Pontides.

Our study confirms that the opening of the Black Sea was diachronous. The rifting of the Western Black Sea Basin predates the Palaeocene-Eocene rifting of the Eastern basin. We show that, at the difference with the Eastern Black Sea Basin, the rifting of the Western Black Sea Basin was very long (40 Myr) and produced a major uplift of the rift shoulders. These two different characteristics indicate that the Western Black Sea Basin, in contrast to the Eastern Black Sea Basin, opened on a thick lithosphere and involved a large depth of necking (about $25 \mathrm{~km}$ ) as proposed by Spadini et al. (1996) and Cloetingh et al. (2003) based on modeling (Fig. 19).

The stratigraphic dating of the Tertiary sequence also constrains the timing of the Pontide compression. We show that along the southern margin of the Black Sea the orogenic movements are also diachronous. They started in the Central Pontides in the Lower Eocene, with the collision of the Kırşehir block.

This work was supported in 2003 and 2004 by the MEBE Programme and in 2006 by TUBITAK (Turkey) (Project No. ÇAYDAG-105Y146) and the University of Savoy (France). We are grateful to Annie Arnaud and J.P. Thieuloy for foraminifer and ammonite determinations. Our thanks go also to Pr. Aral Okay and Pr. Erdins Yiğitbaş for their constructive reviews. 


\section{$\underline{\text { References }}$}

Akat, U., Akçören, F., E.Altun, İ., Devciler E., Göktunalı, K., Keskin, H., Sevin, M., Yıldırım, M., 1990. Geologic Map of the Kastamonu B-17 Quadrangle, 1:100 000. Maden Tetkik ve Arama Genel Müdürlüğü, Ankara.

Akman, A.Ü., 1992. Amasra-Arit arasının jeolojisi. PhD thesis, Ankara University, 209 p.

Aksay, A., Pehlivan, S., Gedik, I., Bilginer, E., Duru, M., Akbas, B., Altun I., 2002. Geological map of Turkey, 1:500 000, Zonguldak Paftası. Maden Tetkik ve Arama Genel Müdürlüğü, Ankara.

Aydın, M, Serdar, H.S., Şahintürk, Ö, Yazman, M., Çokuğraş, R., Demir, O., and Özçelik, Y., 1987. Çamdağ (Sakarya)-Sünnicedağ (Bolu) yöresinin jeolojisi. Geological Society of Turkey Bulletin, 30, 1-14 (in Turkish with English abstract).

Aydın, M, Şahintürk, Ö, Serdar, H.S., Özçelik, Y., Arkasu, I, Üngör, A., Cokugras, R. and Kasar, S., 1986., Ballıdağ-Çangaldağı (Kastamonu) arasindaki bölgenin jeolojisi. Geological Society of Turkey Bulletin, 29, 1-16 (in Turkish with English abstract).

Burchfiel, B.C., 1976. Geology of Romania, Geological Society of America Special Paper, 158, 82

Channell, J.E.T., Tüysüz, O., Bektas, O., and Sengör, A.M.C., 1996. Jurassic-Cretaceous paleomagnetism and paleogeography of the Pontides (Turkey). Tectonics, 15, 201-212.

Cloetingh, S., Spadini, G., Van Wees, J.D., and Beekman, F., 2003. Thermo-mechanical modelling of the Black Sea Basin (de)formation. Sedimentary Geology, 156, 169-184.

Derman, S., 1990. Faylı basen kenarindaki sedimentasyon. Bati Karadeniz' de Kretase' den bir örnek: Türkiye 8. Petrol Kongresi Bildiriler, 314-321.

Derman, S., and Sayılı, A., 1995. İnaltı Formation: a key unit for regional geology. In: Erler, A., Ercan, T., Bingöl, E. and Örçen, S. (eds) Geology of the Black Sea Region, Proceedings of the International Symposium on the Geology of the Black Sea Region. Mineral Research and Exploration Institute of Turkey (MTA), 104-108.

Finetti, I, Bricchi, G., Del Ben, A., Pipan, M., and Xuan, Z., 1988. Geophysical study of the Black Sea. Bolletino di Geofisica ed Applicata, 30, 197-324.

Görür, N., 1988. Timing of opening of the Black Sea Basin. Tectonophysics, 147, 247-262.

Görür, N., 1997. Cretaceous syn- to post-rift sedimentation on the southern continental margin of the Western Black Sea Basin. In: Robinson A.G. (Editor), Regional and petroleum geology of the Black Sea and surrounding region. AAPG Memoir, 68, 227-240.

Görür, N., Oktay, F.Y., Seymen, I., and Şengör, A.M.C., 1984. Paleotectonic evolution of the Tuzgölü basin complex, Central Anatolia: Sedimentary record of a Neo-Tethyan closure. In Dixon, J.E. and Robertson, A.H.F. eds., The geological evolution of the Eastern Mediterranean. Geological Society of London, Special Publication, 17, 455-466.

Görür, N., Tüysüz, O., Aykol, A., Sakinc, M. Yigitbas, E. and Akkök R., 1993. Cretaceous red pelagic carbonates of northern Turkey: Their place in the opening history of the Black Sea. Eclogae Geology Helvetica, 86, 3, 819-838.

Hippolyte, J-C., Angelier, J., Nury, D., Bergerat, F. and Guieu, G., 1993. Tectonic-stratigraphic record of paleostress time changes in the Oligocene basins of the Provence, southern France. Tectonophysics., 226, $15-35$.

Hsü, K.J., Nacev, I.K. and Vuchev, V.T., 1977. Geologic evolution of Bulgaria in the light of plate tectonics. Tectonophysics, 40, 245-256.

Kaymakci, N. 2000. Tectono-stratigraphical evolution of the Çankırı Basin (Central Anatolia, Turkey). Ph.D Thesis, Geologica Ultraiectina. No. 190, Utrecht University Faculty of Earth Sciences, The Netherlands. 232p. 
Kaymakci, N., White, S.H. and van Dijk P.M., 2003a. Kinematic and structural development of the Çankırı Basin (Central Anatolia, Turkey). a paleostress inversion study. Tectonophysics. 364,85-113.

Kaymakci, N.; Duermeijer, C.E.; Langereis, C.; White, S.H.; and van Dijk, P.M. 2003b. Oroclinalbending due to indentation: a paleomagnetic study for the early Tertiary evolution of the Çankiri Basin (central Anatolia, Turkey). Geological Magazine 140, 343-355.

Ketin, I., and Gümüs, Ö, 1963. Sinop-Ayancik arasindaki III. bölgeye dahil sahalarin jeolojisi hakkinda rapor, 2. Kisim, Jura ve Kretase Formasyonlarinin etüdü. Türkiye Petrolleri Arama Grubu Arsivi (unpublished report) No. 213-288, 118 p.

Koçyiğit A., 1991. First remarks on the geology of the Karakaya Basin: Karakaya orogen and pre-Jurassic nappes in eastern Pontides, Turkey, Geologica Romana, 27, 3-11.

Koçyiğit A., and Altıner, D. 2002. Tectonostratigraphic Evolution of the North Anatolian Palaeorift (NAPR): Hettangian-Aptian Passive Continental Margin of the Northern Neo-Tethys, Turkey. Turkish Journal of Earth Sciences, 11, 169-191.

Letouzey, J., Biju-Duval, B., Dorkel, A., Gonnard, R., Kritchev, K., Montadert, L. and Sungurlu, O., 1977. The Black Sea: a marginal basin; geophysical and geological data. In : B., Biju-Duval, and L., Montadert, (eds.), International Symposium on the Structural History of the Mediterranean Basins, Technip, Paris, 363-376.

Manetti, P., Boccaletti, M. and Peccerillo, A., 1988. The Black Sea : remnant of a marginal basin behind the Srednegorie-Pontides island arc system during the Upper Cretaceous-Eocene times. Bolletino di Geofisica Teorica ed Applicata, 30, 39-51.

Nikishin, A.M., Korotaev, M.V., Ershov, A.V. and Brunet, M.F., 2003. The Black Sea basin: tectonic history and Neogene-Quaternary rapid subsidence modelling. Sedimentary Geology, 156, 149-168.

Okay, A. I., Şengör, A.M.C. and Görür, N., 1994. Kinematic history of the opening of the Black Sea and its effect on the surrounding regions, Geology, 22, 267-270.

Okay, A.I., and Tüysüz, O., 1999. Tethyan Sutures of northern Turkey. In: Durand, B., Jolivet, L, Horvath, F. and Séranne, M. The Mediterranean Basins: Tertiary extension within the Alpine Orogen. Geological Society London, Special Publication, 156, 475-515.

Okay, A.I., Tüysüz, O., Satır, M., Özkan-Altıner, S., Altıner, D., Sherlock, S., and Eren, R.H., 2006. Cretaceous and Triassic subduction-accretion, high-pressure-low-temperature metamorphism, and continental growth in the Central Pontides, Turkey. Geological Society of America Bulletin, 118, 12471269.

Robinson, A., 1997. Introduction: Tectonic elements of the Black Sea region. In: Robinson, A. (Ed.), Regional and petroleum geology of the Black Sea and surrounding region, American Association of Petroleum Geologists Memoir, 68, 1-6.

Robinson, A., Rudat, J. H., Banks, C. J. and Wiles, R. L. F., 1996. Petroleum geology of the Black Sea. Marine and Petroleum Geology, 13, 195-223.

Robinson, A., Spadini, G., Cloeting, S., and Rudat, J., 1995. Stratigraphic evolution of the Black Sea inferences from basin modeling. Marine and Petroleum Geology, 12, 8, 821-835.

Rosenbaum G., Lister G.S., and Duboz, C., 2002. Relative motions of Africa, Iberia and Europe during Alpine orogeny. Tectonophysics, 359, 117-129.

Sandulescu, M., 1978. The Moesic Platform and the North Dobrogean orogen. In: Lemoine, M. (Ed.), Geological atlas of Alpine Europe and adjoining areas. Elsevier, Amsterdam, 427-460.

Siyako, M., Aksoy, Z., Bürkan, K.A., and Demir, O., 1981. Zonguldak dolayinin jeolojisi ve hidrokarbon olanakları: Türkiye Petrolleri A.O. Arama Grubu Arsivi (unpublished report), No. 1536, 72p.

Spadini, G., Robinson, A. and Cloeting, S., 1996. Western versus Eastern Black Sea tectonic evolution: prerift lithosphere controls on basin formation. Tectonophysics, 266, 139-154. 
Sunal, G. and O., Tüysüz, 2002. Palaeostress analysis of Tertiary post-collosional structures in the Western Pontides, northern Turkey. Geological Magazine, 139, 343-359.

Tokay M., 1952. Contribution à l'étude géologique de la region comprise entre Eregli, Alaplı, Kızıltepe et Alacaağzı. Maden Tetkik ve Arama Enstitüsü Mecmuası, 42-43, 37-78.

Tüysüz, O., 1990. Tectonic evolution of a part of the Tethyside orogenic collage: the Karg1 Massif, northern Turkey, Tectonics, 9, 141-160.

Tüysüz, O., 1999. Geology of the Cretaceous sedimentary basins of the Western Pontides, Geological Journal, 34, 75-93.

Ustaömer, T. and Robertson, A.H.F., 1997, Tectonic-sedimentary evolution of the North-Tethyan margin in the Central Pontides of northern Turkey, in Robinson, A.G., ed., Regional and petroleum geology of the Black Sea and surrounding region. American Association of Petroleum Geologists Memoir 68, 255290.

Verzhbitsky, E., Kuzin, I., and Lobkovsky, L., 2002, Age and thickness of the lithosphere within the Western and Eastern Basins of the Black Sea according to geophysical data. Turkish Journal of Earth Sciences, 11, 231-242.

Yergök, A.F., Akman, Ü., Keskin, İ., İplikçi, E., Mengi, H., Karabalık, N.N., Umut, M., Armağan, F., Erdoğan, K., Kaymakçı, H., Çetinkaya, A., 1987. Batı Karadeniz Bölgesinin Jeolojisi (I), 1:100 000. Maden Tetkik ve Arama Genel Müdürlüğü, Ankara.

Yergök, A.F., Akman, Ü., Tekin, F., Karabalık, N.N., Arbaş, A., Umut, M., Armağan, F., Erdoğan, K., Kaymakçı, H., 1989. Batı Karadeniz Bölgesinin Jeolojisi (II), 1:100 000. Maden Tetkik ve Arama Genel Müdürlüğü, Ankara.

Yiğitbaş, E., Elmas, A., Yılmaz, Y., 1999. Pre-Cenozoic tectono-stratigraphic components of the Western Pontides and their geological evolution. Geological Journal, 34, 55-74.

Yiğitbaş, E., Kerrich, R., Yılmaz, Y., Elmas, A., Xie, Q., 2004. Characteristics and geochemistry of Precambrian ophiolites and related volcanics from the Istanbul-Zonguldak Unit, Northwestern Anatolia, Turkey: following the missing chain of the Precambrian South European sutre zone to the east. Precambrian Research, 132, 179-206.

Yılmaz, Y., Tüysüz, O., Yigitbas, E., Can Genç, S. and Sengör, A.M.C., 1997. Geology and tectonic evolution of the Pontides. In: Robinson, A.G. (Ed.), Regional and petroleum geology of the Black Sea and surrounding region, American Association of Petroleum Geologists Memoir, 68, 255-290.

Zonenshain, L.P. et Le Pichon, X., 1986. Deep basins of the Black Sea and Caspian Sea as remnants of Mesozoic back-arc basins, Tectonophysics, 123, 181-211. 


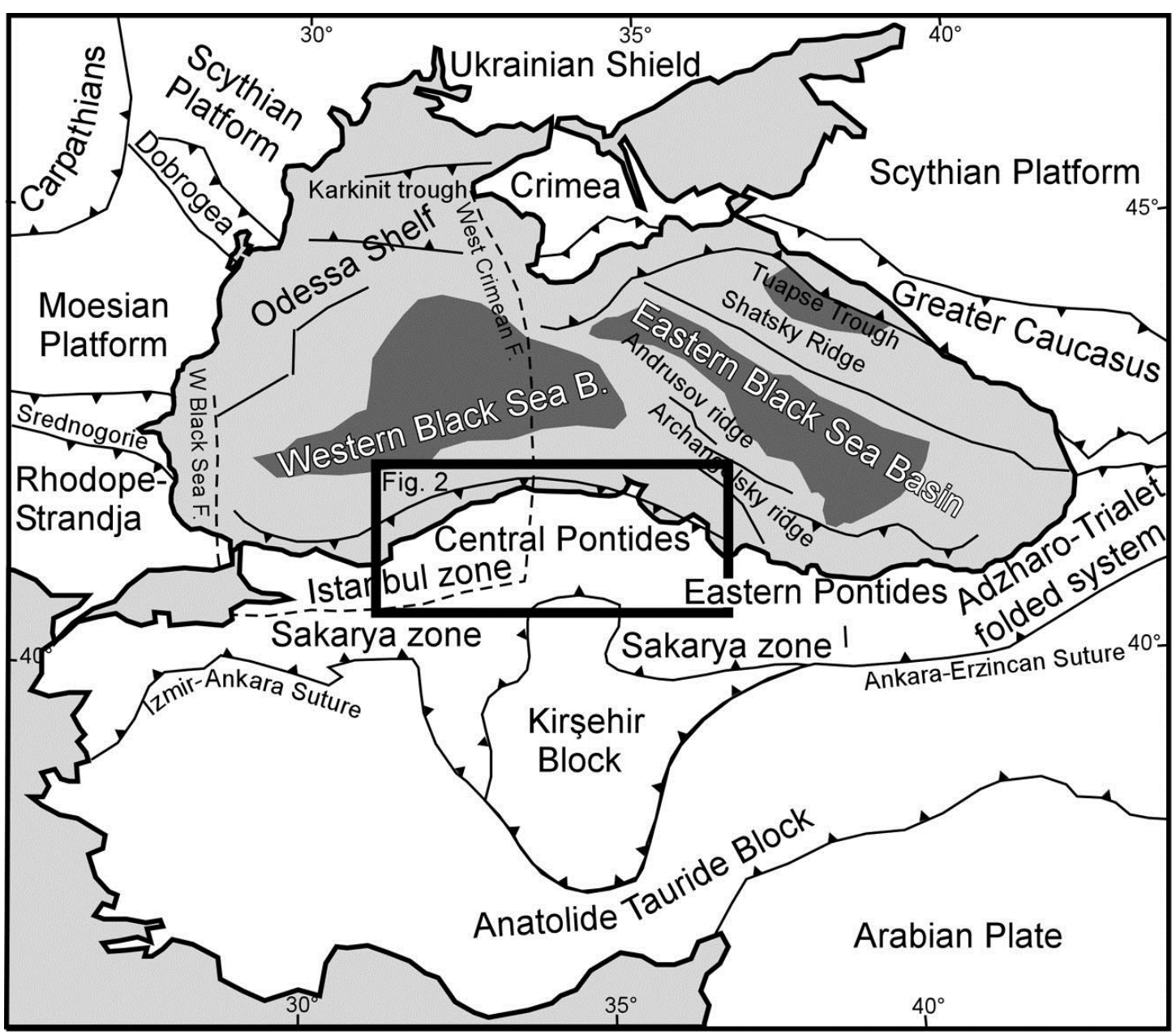

Fig. 1: Location of the arc of Central Pontides between the Western Black Sea Basin and the Kirşehir Block (modified after Robinson et al., 1996; Robinson, 1997; Okay and Tüysüz, 1999).

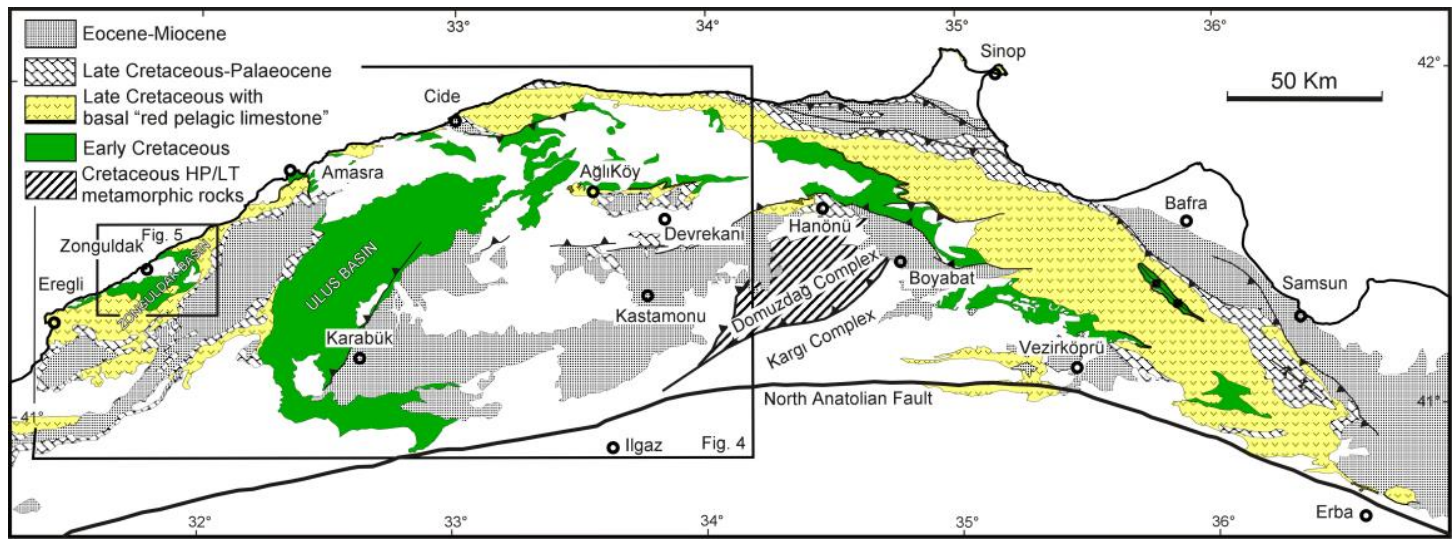

Fig. 2: Structural sketch of the Central Pontides arc with location of the studied area (Fig. 5) and the Lower Cretaceous basins. The north Anatolian fault runs through the subduction complexes. 


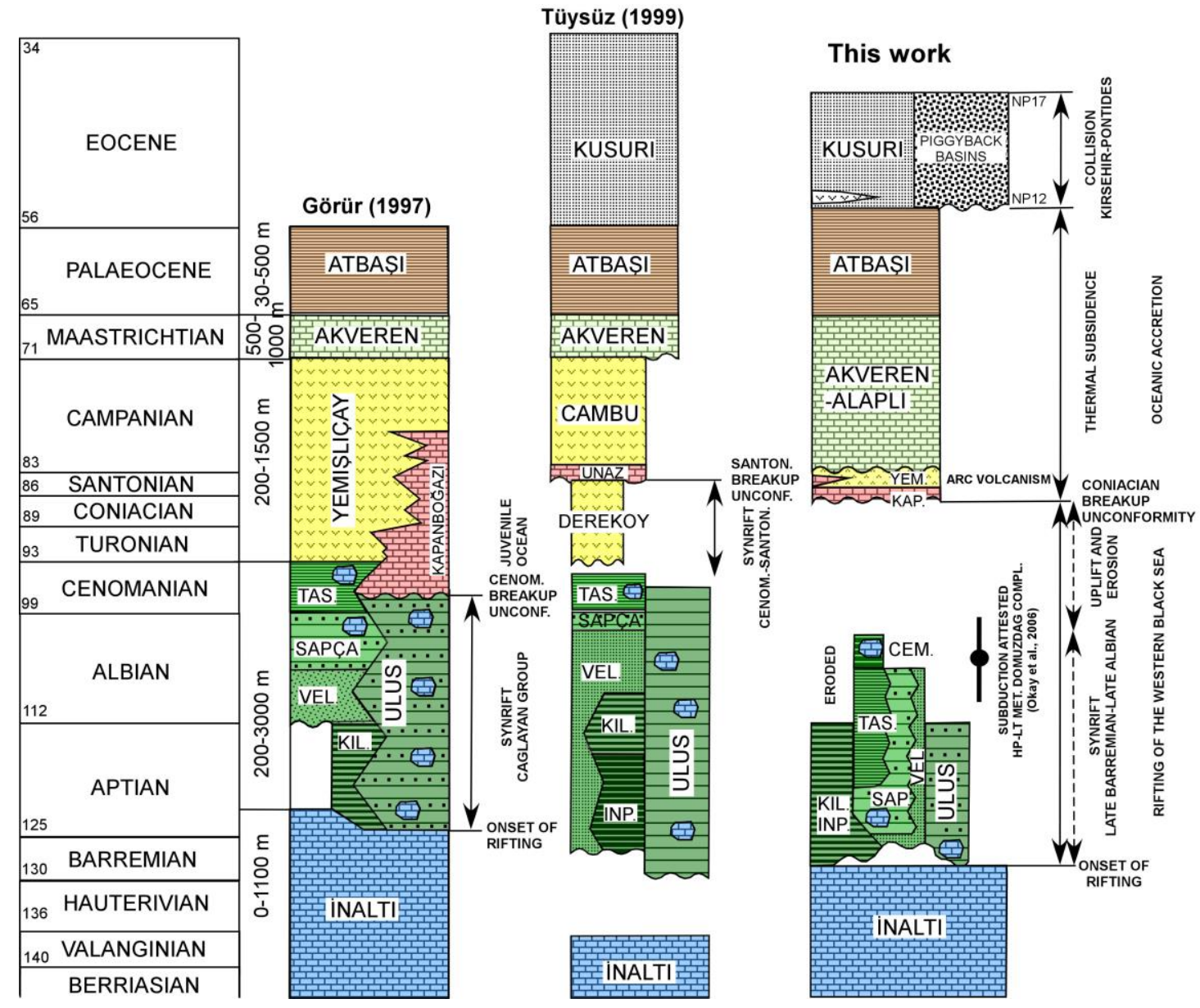

Fig. 3: Comparison of dating of the stratigraphic formations of the Central Pontides (Black Sea coast, Zonguldak Basin and Ulus Basin). CEM: Cemaller Formation; INP, İnpiri Formation; KAP: Kapanboğazı Formation; KIL: Kilimli Formation; SAP: Sapça; TAS: Tasmaca Formation; YEM: Yemişliçay Formation; VEL: Velibey Formation.

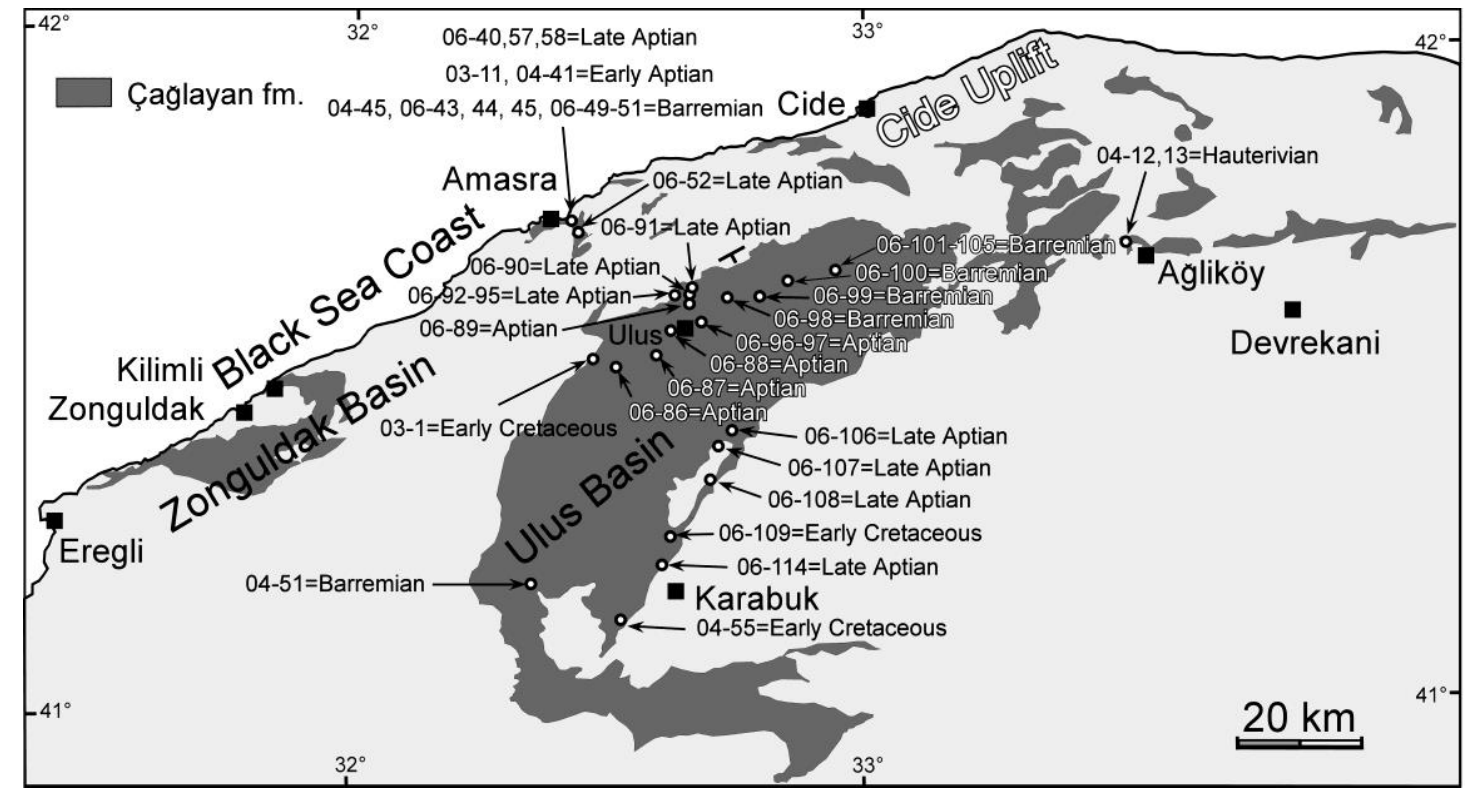

Fig. 4: The Early Cretaceous Çağlayan Group and its sites of nannoplankton dating (c.f. Table 1). 


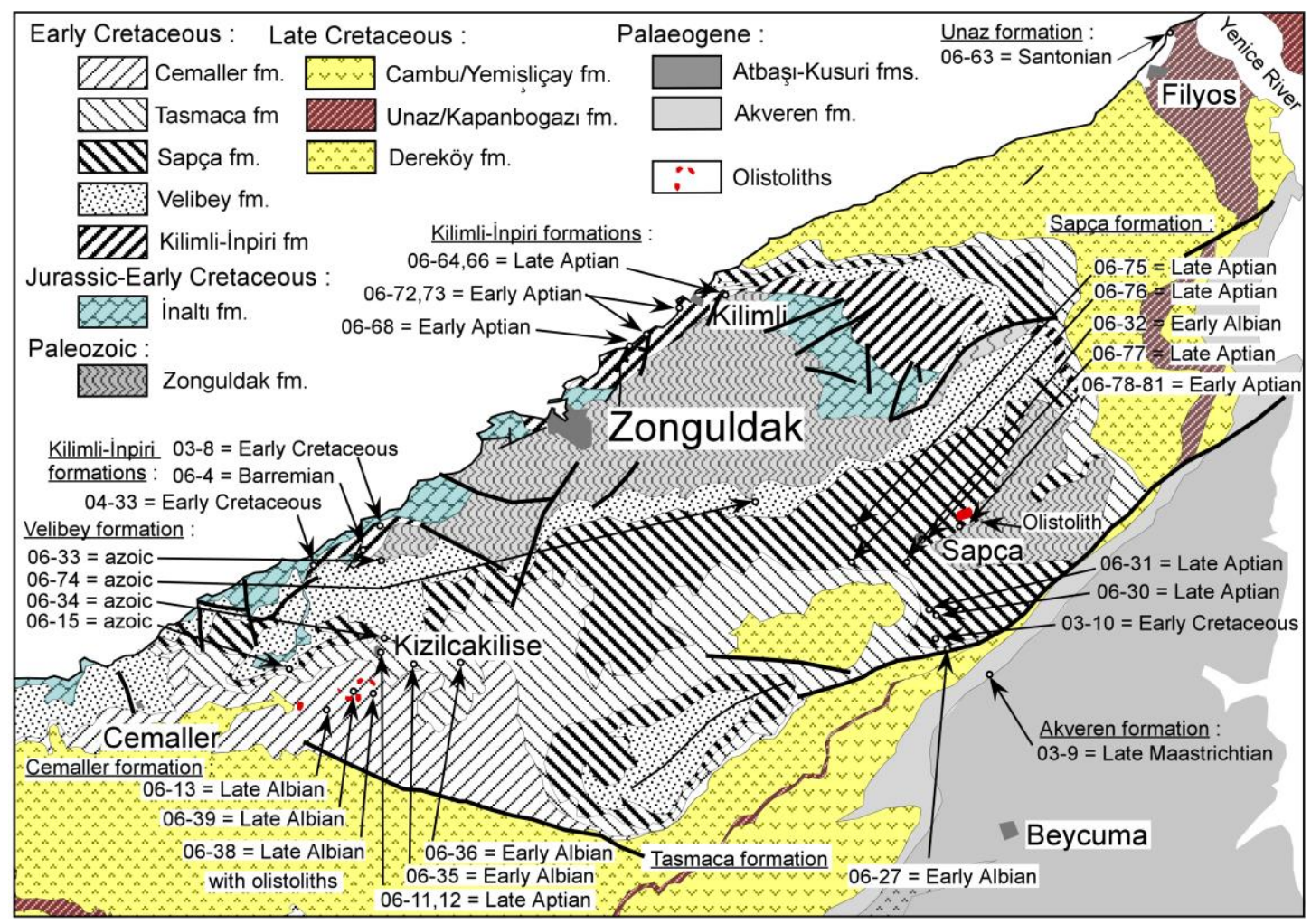

Fig. 5: The formations of the Early Cretaceous Çağlayan Group around Zonguldak (Yergök et al., 1989; location on Fig. 2) with sites of nannoplankton dating.

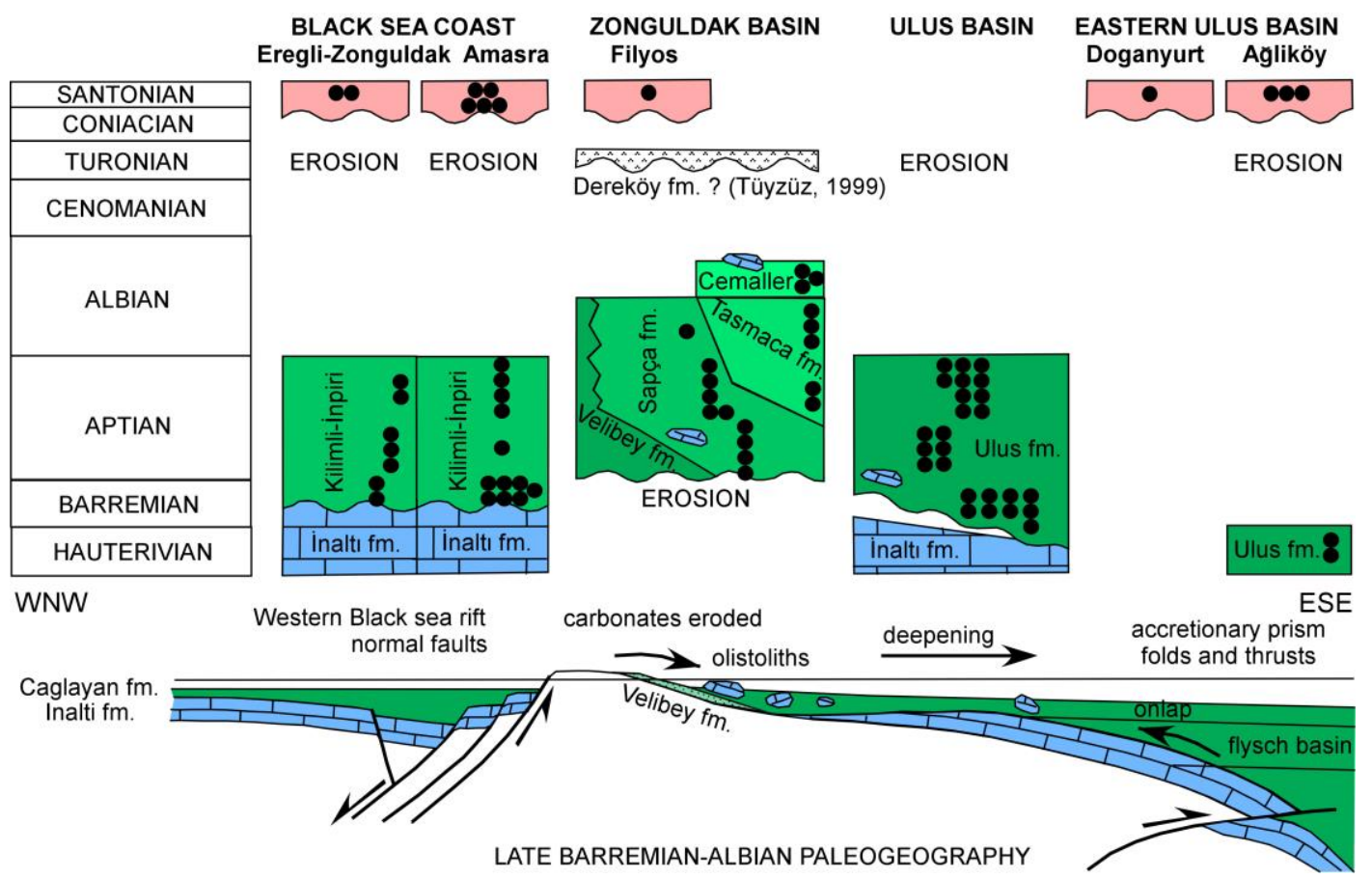

Fig. 6: Stratigraphic position of the samples (each dot represents a sample with precise nannoplankton dating) and tentative paleogeographic interpretation of the facies and age of the Çağlayan Group on a NW-SE section. 


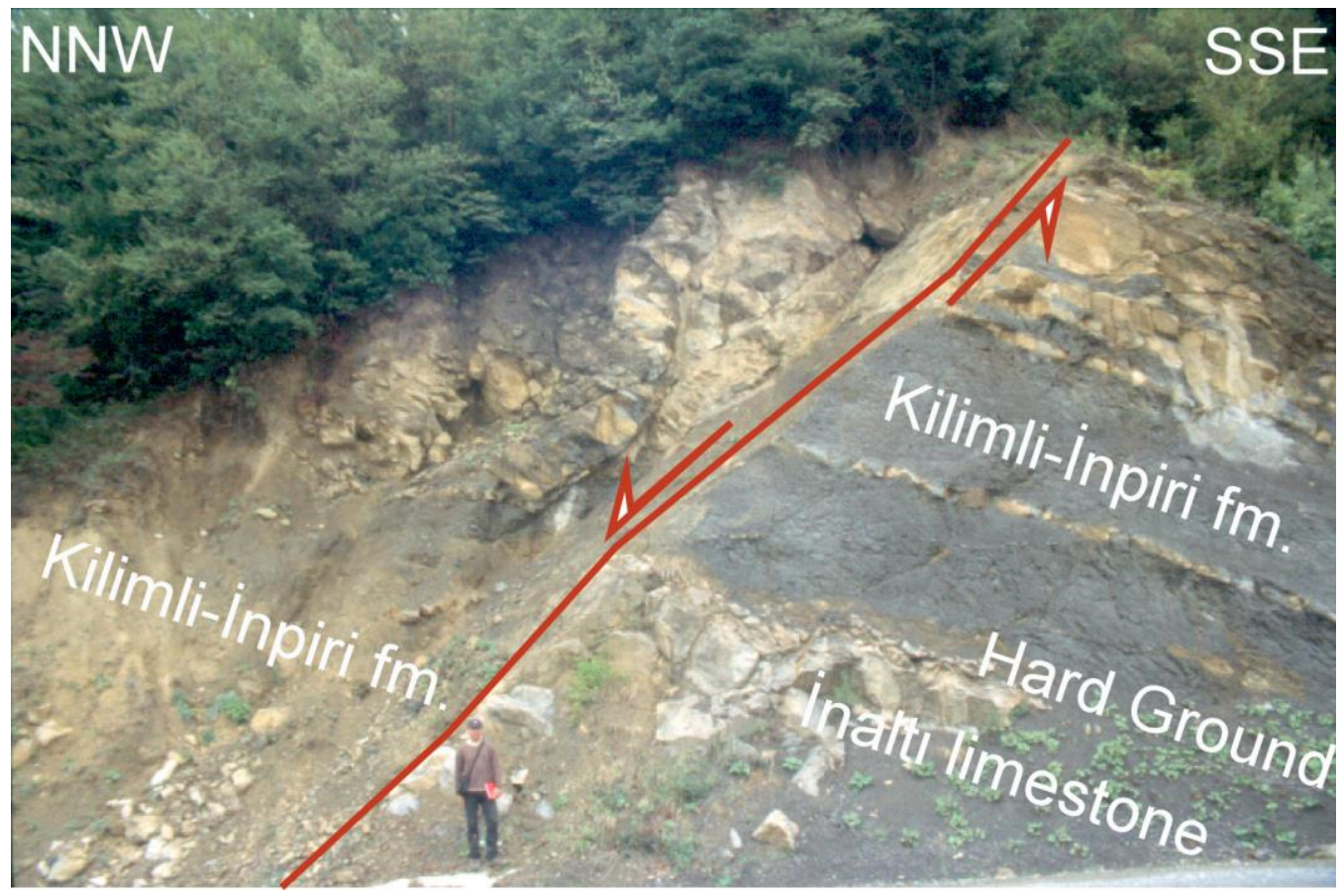

Fig. 7: Stratigraphic contact of the Barremian-Aptian Kilimli-İnpiri Formation (Çağlayan Group) on the İnaltı Jurassic-Neocomian limestone west of Zonguldak (near site 06-4 of Barremian age, Fig. 5). Along the Black Sea coast, the Çağlayan Formation was cut by numerous normal faults like this one.

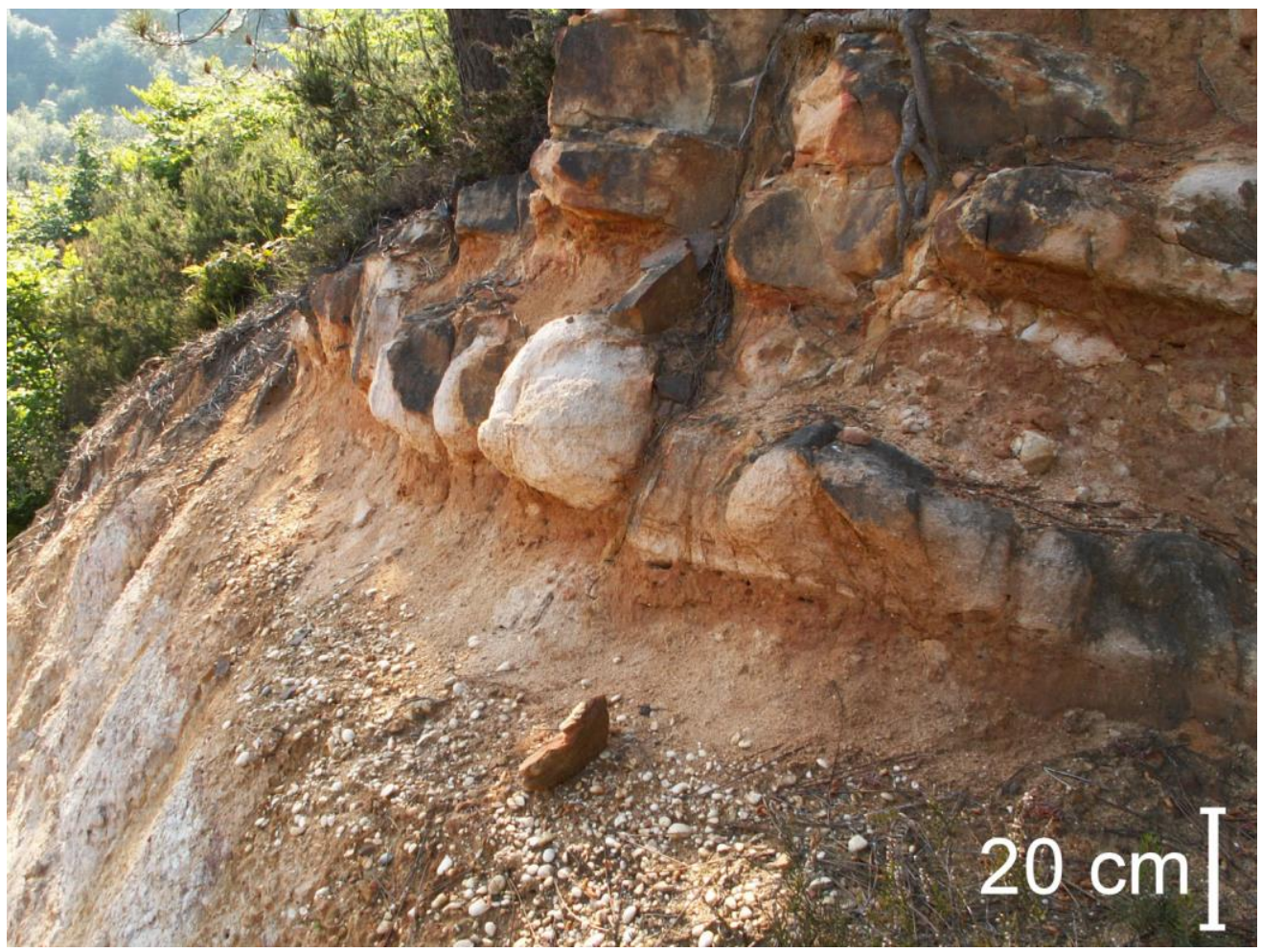

Fig. 8: Velibey Formation (Çağlayan Group) near Kızılcakilise (Fig. 5). Barren (continental) sandstones and gravels. 


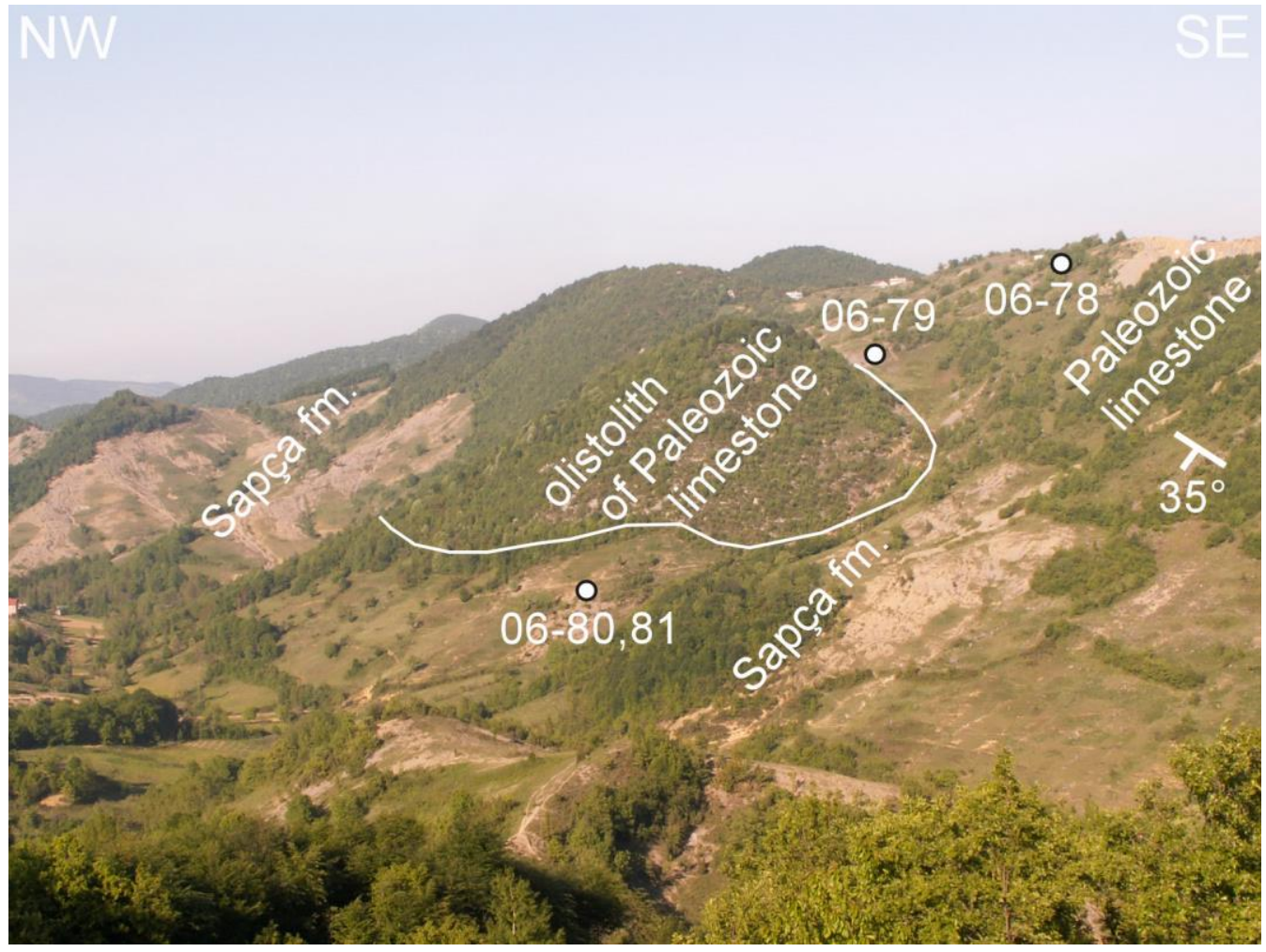

Fig. 9: Sapça Formation (Çağlayan Group) at Sapça (Fig. 5), with an olistolith of Paleozoic limestone (Zonguldak Formation). Samples 06-78 to 06-81 are Lower Aptian.

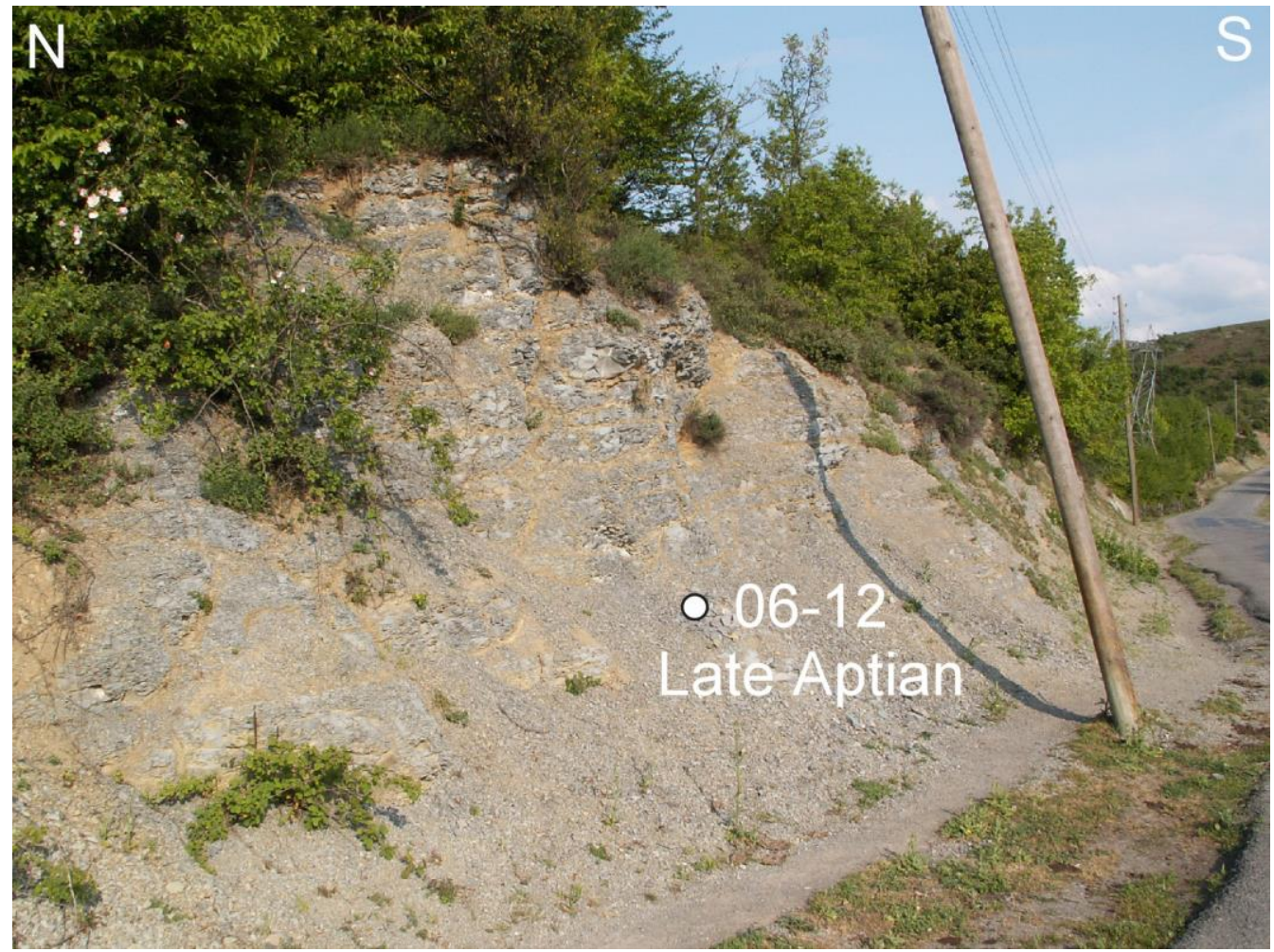

Fig. 10: Tasmaca Formation (Çağlayan Group) at Kizilcakilise (Fig. 5). Samples 06-12 and 06-11 (in the village) are Upper Aptian. The top of the formation is Lower Albian (samples 06-35,36, Fig. 5). 


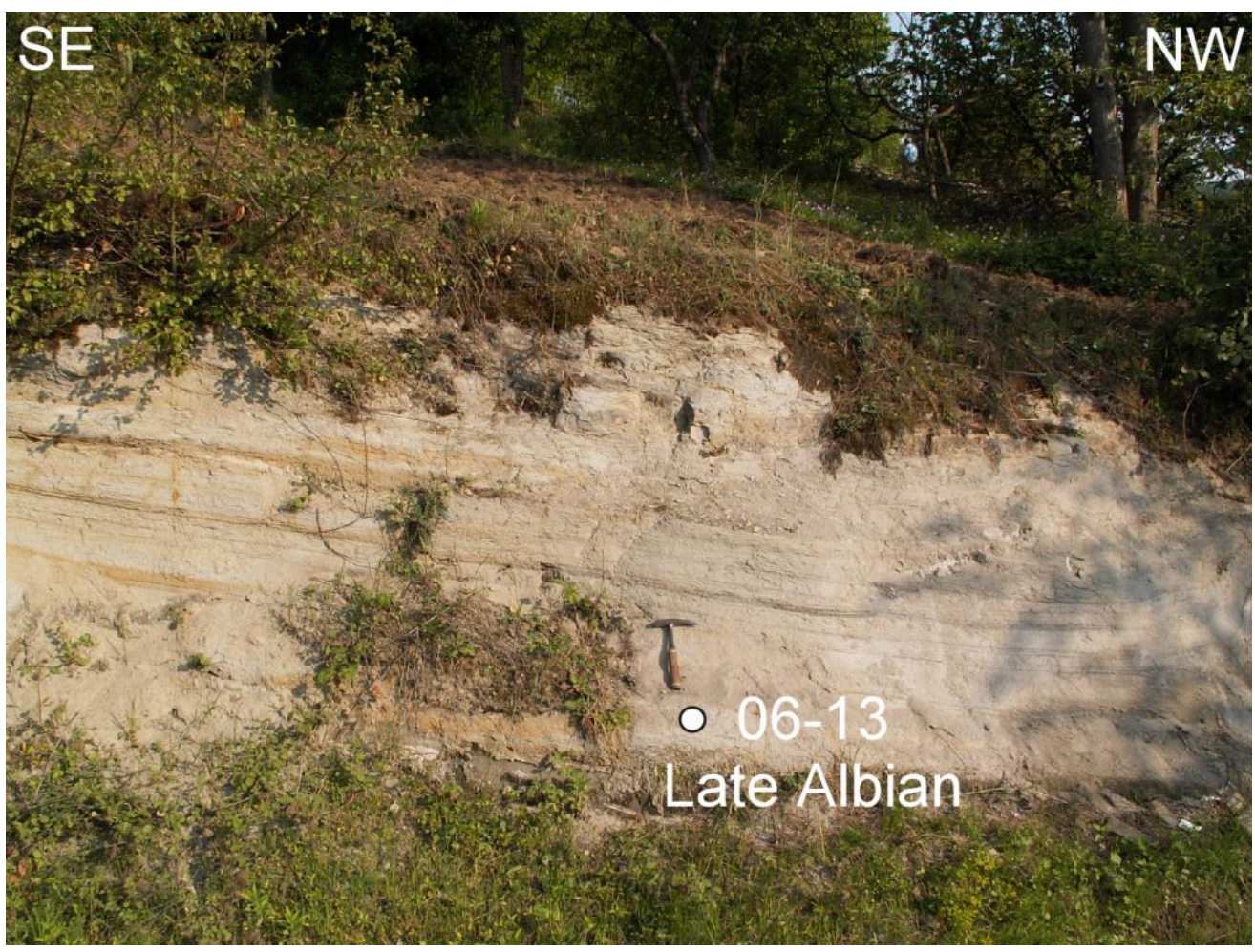

Fig. 11: Cemaller Formation (Çağlayan Group) at site 06-13 between Kizilcakilise and Cemaller (Fig. 5). Marls and sands with thin coal intercalations (in dark). At neighboring sites 6-38 and 6-39 with olistoliths, nannoplanktons also indicate a Upper Albian (first part) age.

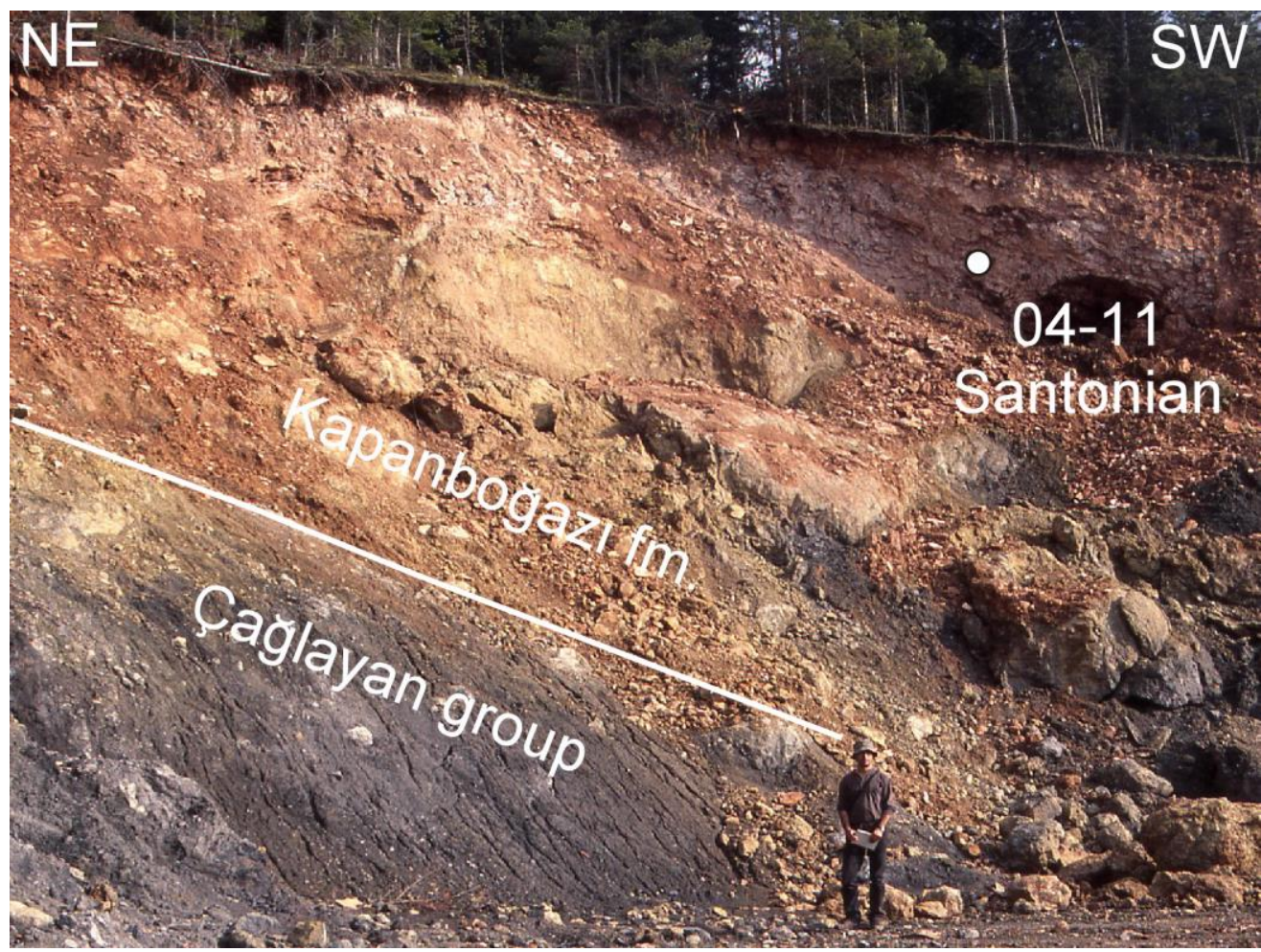

Fig. 12: Unconformity of the Kapanbogazy red pelagic limestone (Santonian, samples 04-11, 15, 16) on the Çağlayan sandstone (Hauterivian-Barremian, samples 04-12, 13, 19) near Ağlıköy (Fig. 4). 


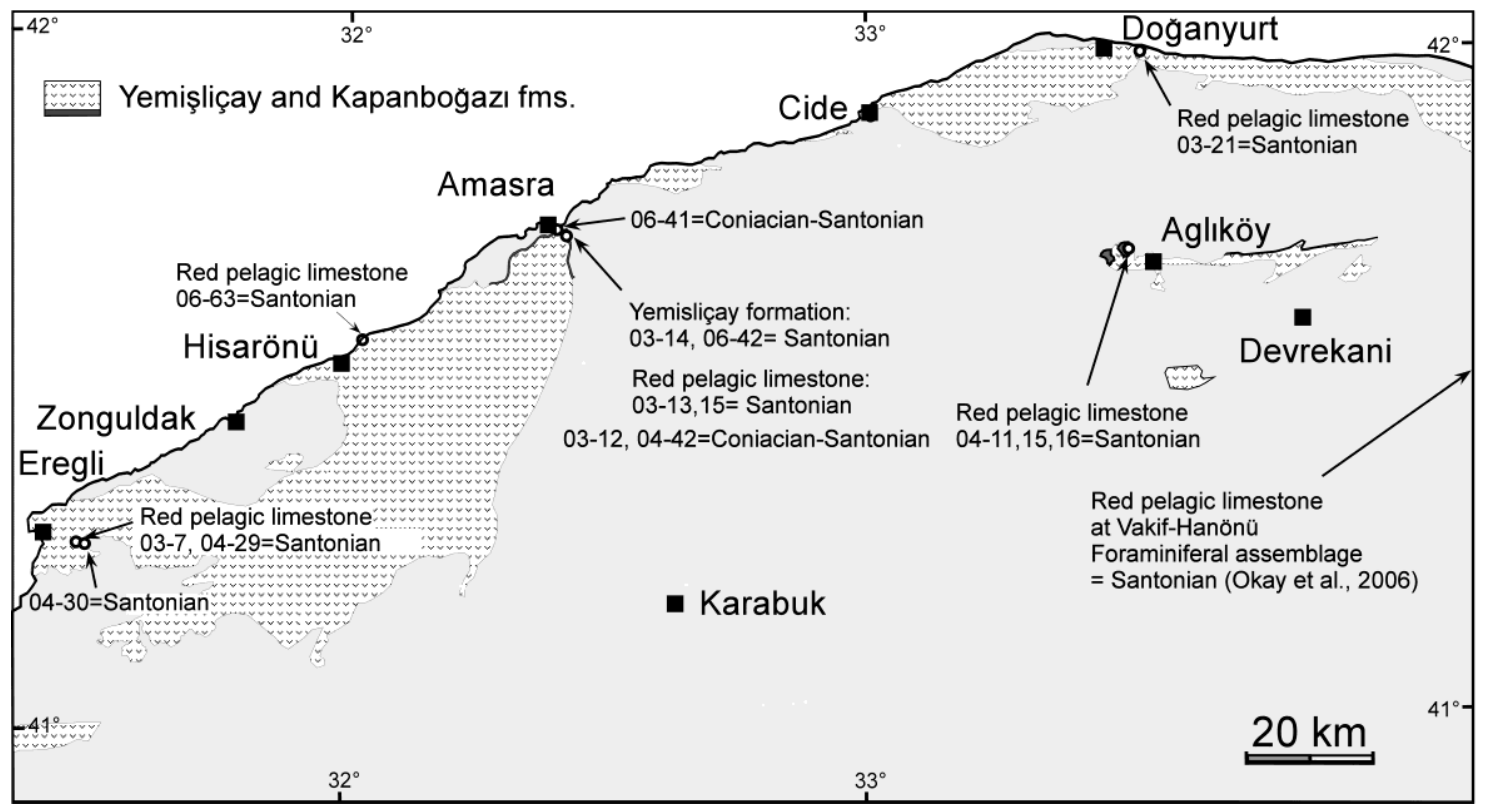

Fig. 13: Late Cretaceous Kapanboğazı and Yemişliçay Formations with their sites of nannoplankton dating (c.f. Table 1).

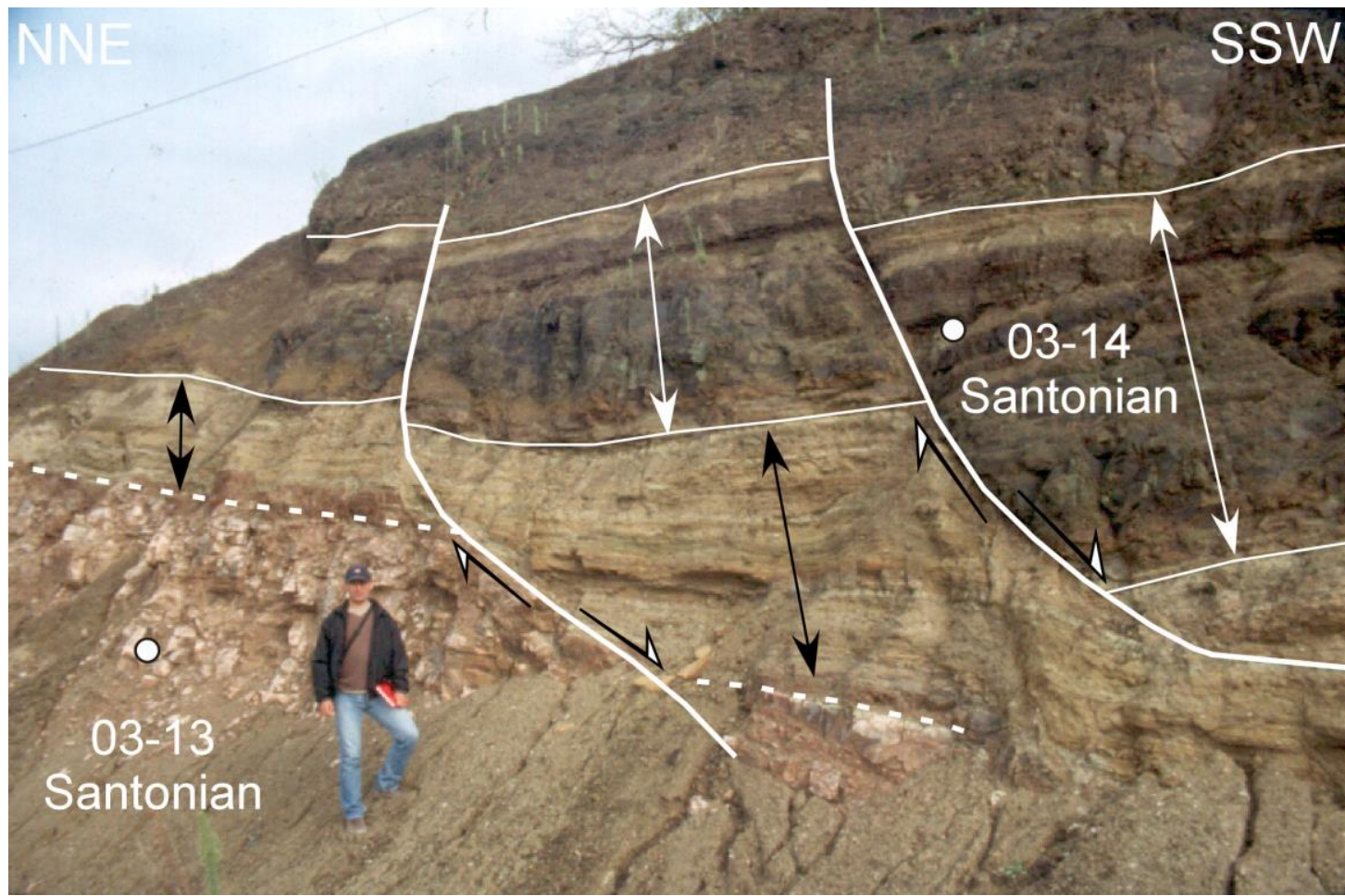

Fig. 14: Kapanboğazı (red pelagic limestone) and Yemişliçay (volcaniclastic sediments) Formations at Amasra

(Fig. 13). These formations are cut by syndepositional listric normal faults. The layers of the Yemişliçay Formation are thicker in the downthrown blocks. A syn-tectonic wedge of clays of the Yemişliçay Formation is dated from the Santonian (03-14). The red limestones are also Santonian (samples 03-13 and 06-42). 

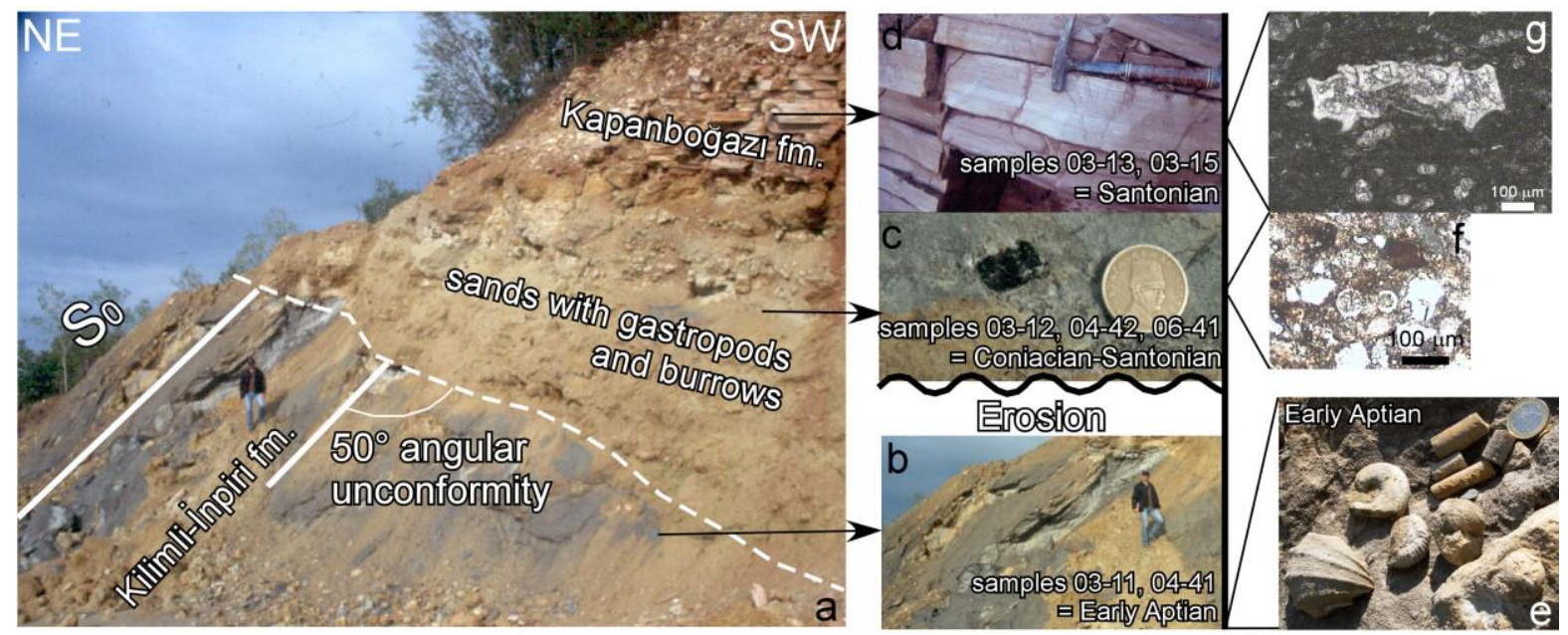

Fig. 15: Angular unconformity of the Late Cretaceous on the Early Cretaceous at Amasra (Fig. 13).

(A) The black shales of the Kilimli-İnpiri Formation (Çağlayan Group) are tilted to the West and are overlain by yellowish sands and red limestone of the Kapanboğazı Formation. (B) The Kilimli-İnpiri Formation is dated with nannoplankton from Barremian (06-43, 06-44) to Lower Aptian (under the unconformity, samples 03-11, 04-41). (C, D) The yellow sands are Coniacian-Santonian, and the red limestones are Santonian. Even if the very first layers above the İnaltı shelf carbonates of the Kilimli-Inpiri Formation are Barremian, the base of the sequence already contains echinoids, gastropods, belemnites and ammonites (E) of Lower Aptian age. The yellow sands contain clasts of coal from erosion of the nearby Carboniferous sequence $(\mathrm{C})$. Shallow marine environment is indicated by gastropods, burrows and abundant little planktonic foraminifers (F). In contrast, the Kapanboğazı limestone is characterized by large planktonic foraminifers (Globotruncanidae) indicative of a much deeper environment $(\mathrm{G})$.

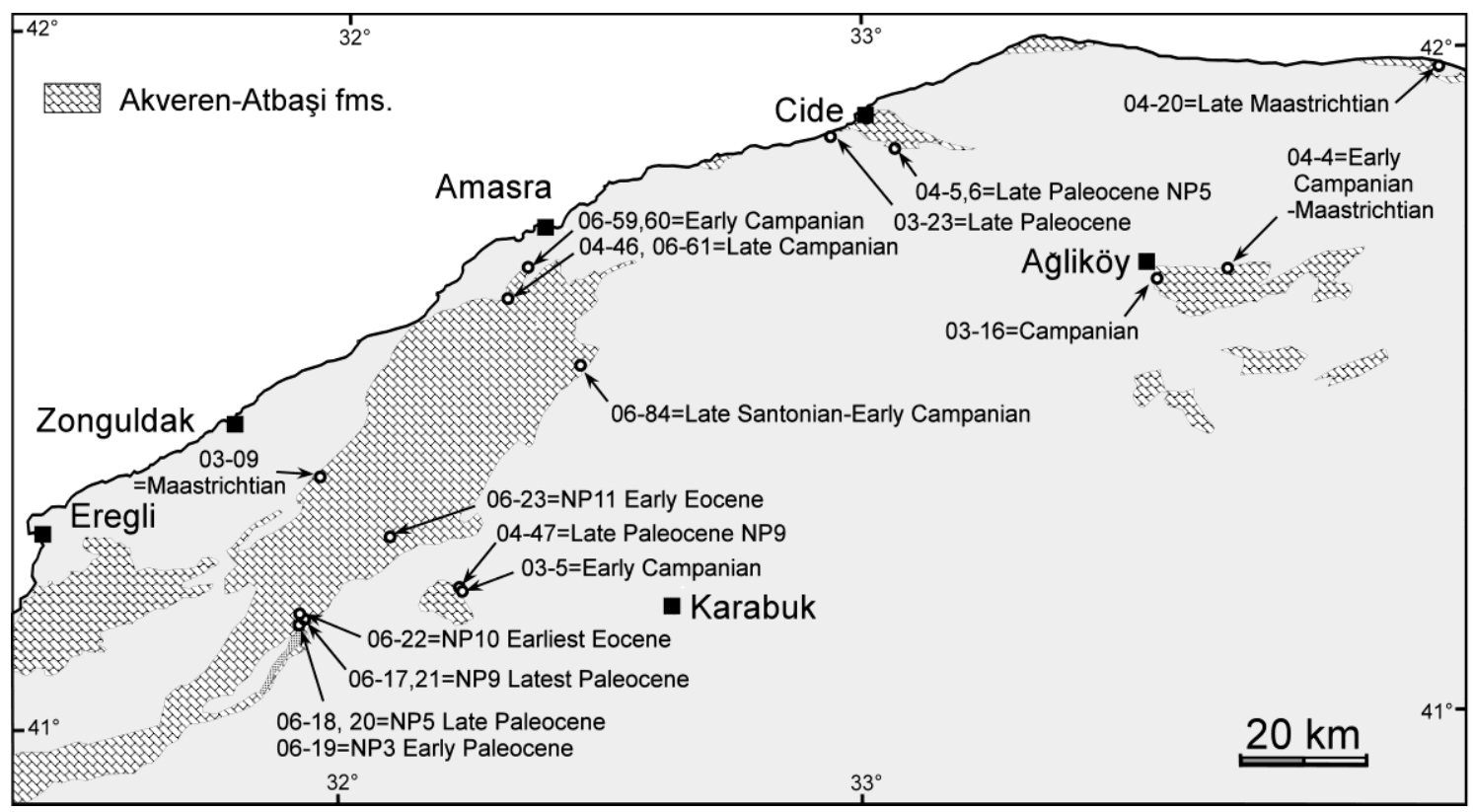

Fig. 16: Campanian-Palaeocene Akvenren and Atbaşı Formations with their sites of nannoplankton dating (c.f. Table 1). 


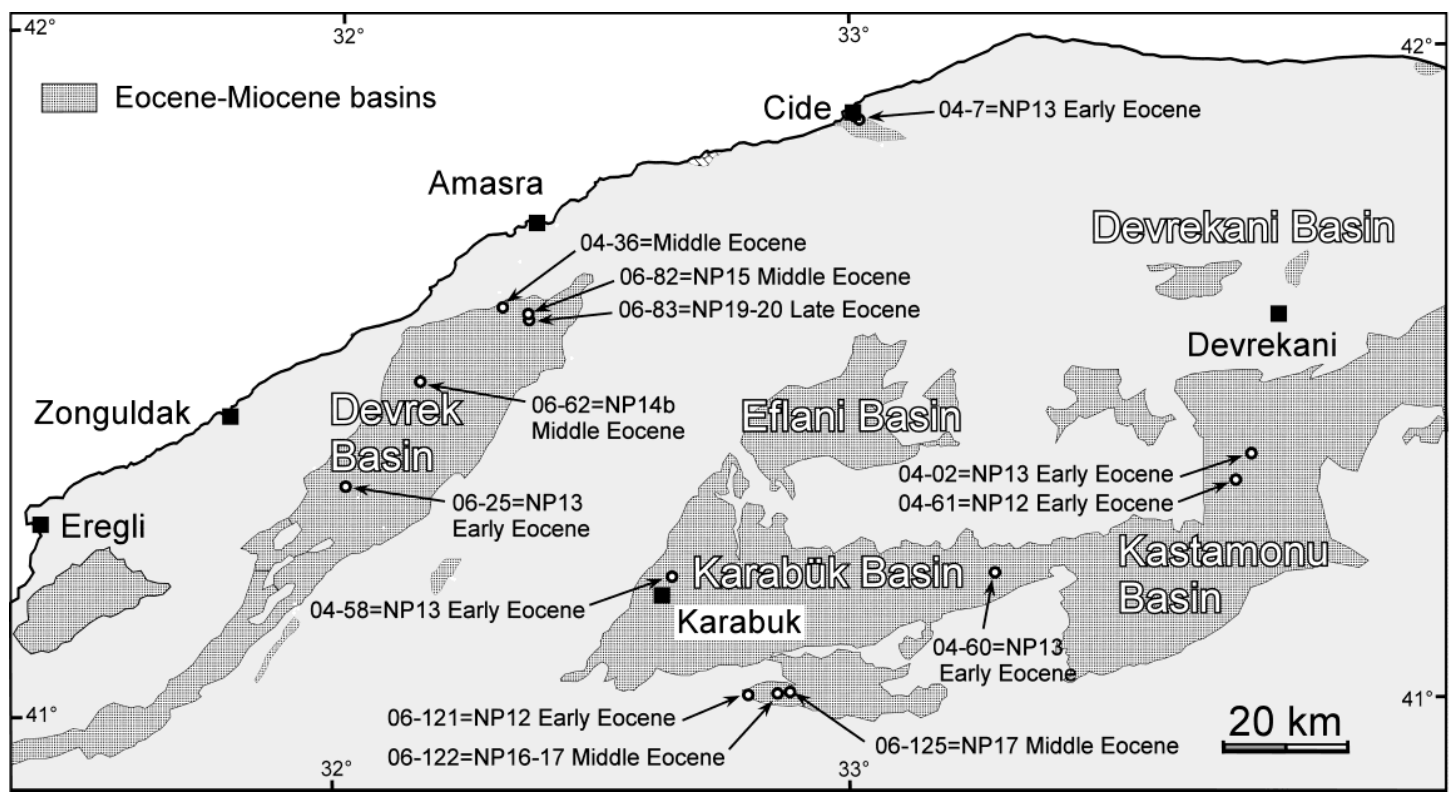

Fig. 17: Eocene-Miocene basins with their sites of nannoplankton dating (c.f. Table 1). During Eocene piggyback basins are created within the Pontide trust belt. Eocene marine sediments range from NP12 to NP17 in the Eflani, karabük and Kastamonu piggyback basins. Marine sediments up to NP19-20 (Upper Eocene) were found in the Devrek Basin.

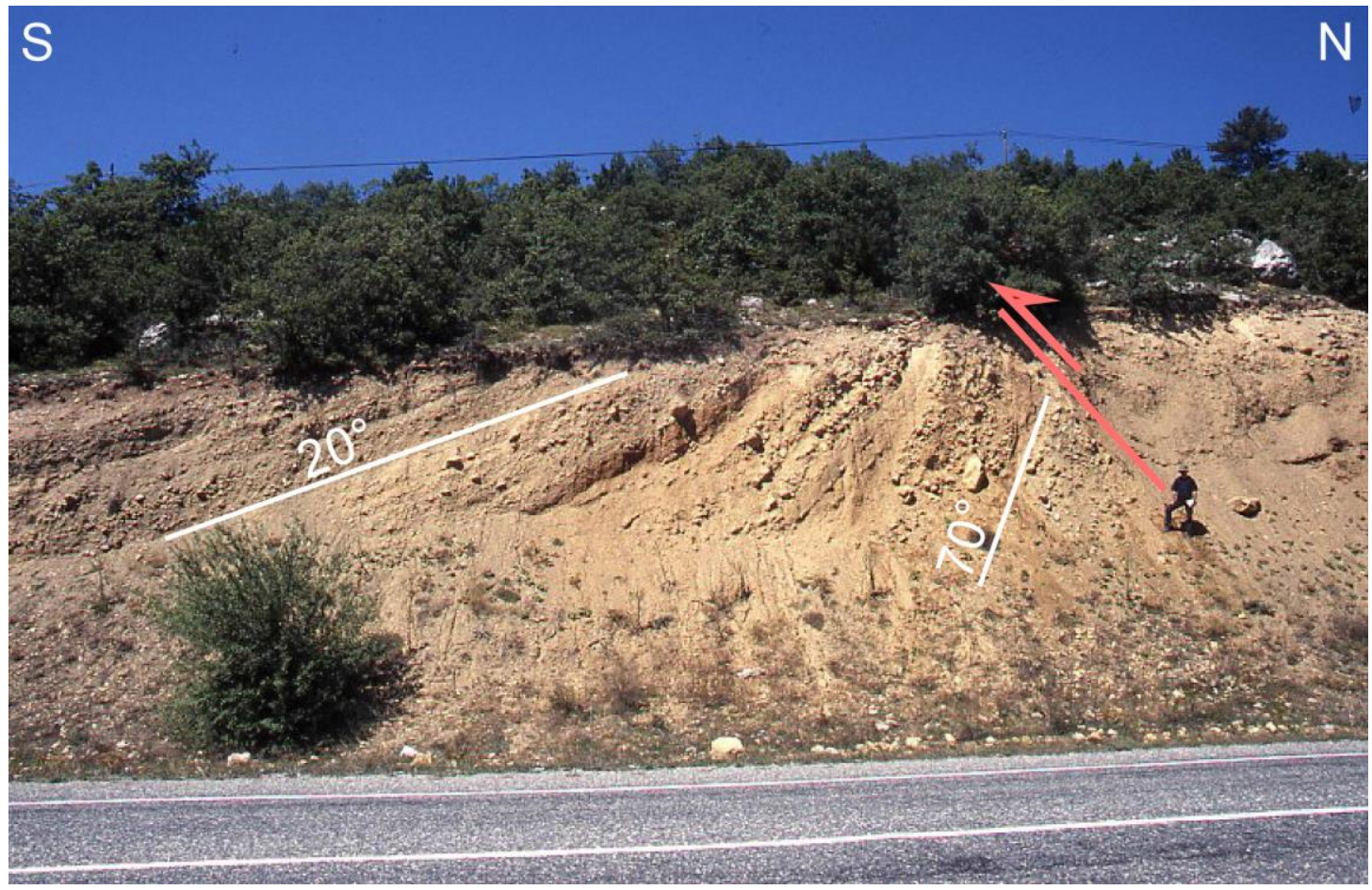

Fig. 18: Stratigraphic wedging at the front of a reverse fault along the northern margin of the Kastamonu Eocene basin. Such intra-formational angular unconformities at the border of the Eocene basins demonstrate that they are syn-compressional piggyback basins. 


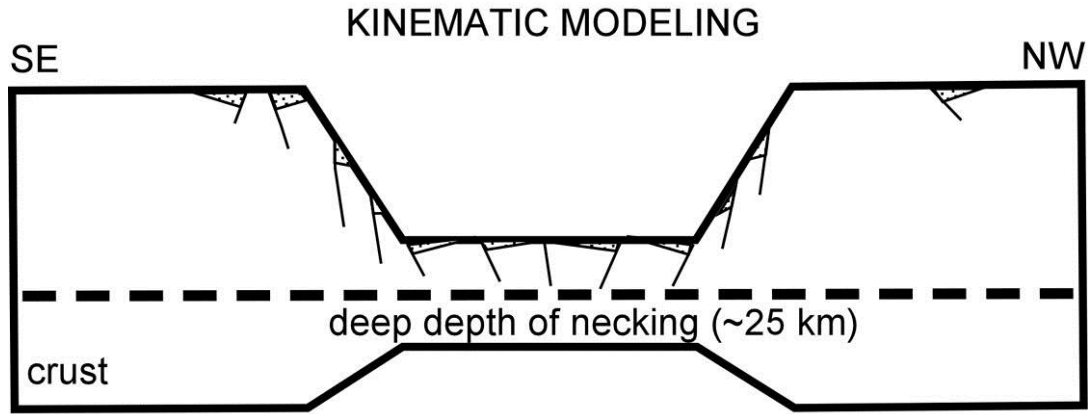

A mantle

REGIONAL ISOSTATIC RESPONSE:

LATE ALBIAN-CONIACIAN UPWARD FLEXURE
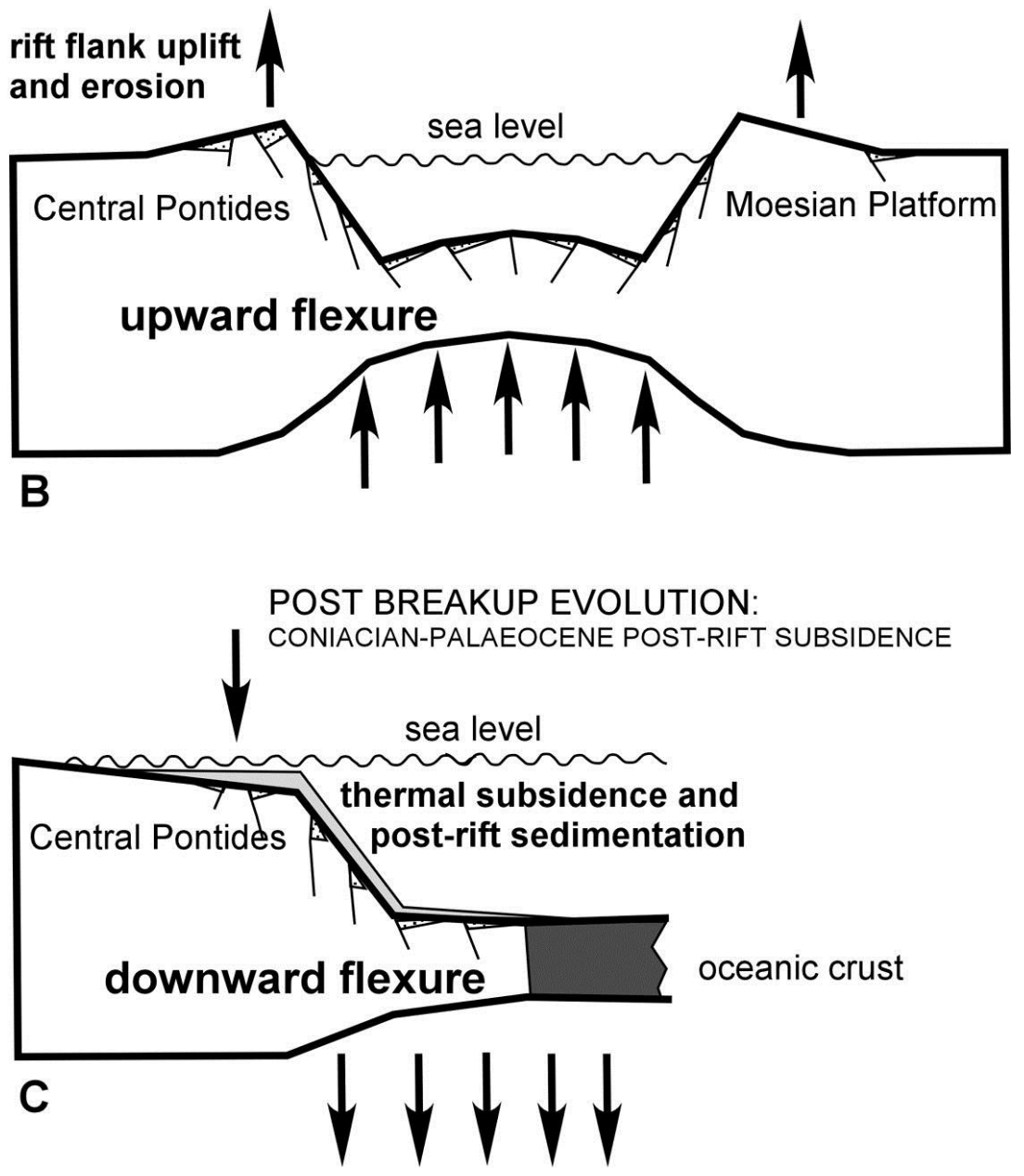

Fig. 19: The rifting of the Western Black Sea Basin in relation with the concept of lithospheric necking. Stratigraphic data show that the rifting started in Late Barremian and was very long, 40 Myrs. In the central Pontides, during the rifting, the change from sedimentation to erosion denotes rift flank uplift starting in Late Albian. These results support the models of rifting of a thick (cold) lithosphere with a large depth of necking (level of no vertical motions in the absence of isostatic forces) (Figs. A and B, modified from Spadini at al., 1996). Note that in the case of the Black sea the uplift of the southern rift shoulders might have been enhanced by the collision of the Kargi continental block. Following the continental breakup the margin subsided and the post-rift deposits onlapped the Central Pontides in Coniacian-Santonian (Fig. C). 


\begin{tabular}{|c|c|c|c|c|}
\hline $\begin{array}{l}\text { Longitude } \\
\text { UTM36 }\end{array}$ & $\begin{array}{l}\text { Latitude } \\
\text { UTM36 }\end{array}$ & Sample Name & Formation names & Nannoplankton Age \\
\hline 458996 & 4596877 & $03-1$ & Caglayan, Ulus & Early Cretaceous \\
\hline 456035 & 4598317 & $03-2$ & Caglayan, Ulus & Early Cretaceous \\
\hline 435771 & 4562960 & $03-5$ & Akveren-Atbasi & Lower Campanian \\
\hline 373397 & 4570272 & $03-7$ & Yemisliçay, Kale & Coniacian-Santonian \\
\hline 392428 & 4586435 & $03-8$ & Caglayan, Kilimli & Early Cretaceous \\
\hline 412724 & 4581106 & $03-9$ & Akveren & Upper Maastrichtian-Eocene \\
\hline 411056 & 4582529 & $03-10$ & Caglayan, Sapça-Himmetoglu & Early Cretaceous \\
\hline 452433 & 4621005 & 03-11 & Caglayan, Kilimli & Lower Aptian \\
\hline 452433 & 4621005 & $03-12$ & Cemaller & Coniacian \\
\hline 452433 & 4621005 & $03-13$ & Kapanbogazi, Basköy & Santonian \\
\hline 452433 & 4621005 & $03-14$ & Yemisliçay, Dilence & Santonian \\
\hline 452433 & 4621005 & $03-15$ & Kapanbogazi, Basköy & Coniacian-Santonian \\
\hline 547642 & 4613153 & $03-16$ & Akveren-Atbasi & Campanian \\
\hline 554238 & 4617551 & $03-17$ & Caglayan & Early Cretaceous \\
\hline 544191 & 4649177 & $03-21$ & Yemisliçay & Santonian \\
\hline 495198 & 4635760 & $03-23$ & Akveren-Atbasi & Upper Palaeocene \\
\hline 452595 & 4620704 & $03-24$ & Kilimli & Aptian \\
\hline 565862 & 4583615 & $04-2$ & Kusuri & Lower Eocene NP13 \\
\hline 559198 & 4614685 & $04-4$ & Akveren-Atbasi & Lower Campanian-Maastrichtian \\
\hline 505499 & 4633850 & $04-5$ & Akveren-Atbasi & Upper Paleocene NP5 \\
\hline 505499 & 4633850 & $04-6$ & Akveren-Atbasi & Upper Paleocene NP5 \\
\hline 501158 & 4638416 & $04-7$ & Kusuri & Lower Eocene NP13 \\
\hline 493185 & 4634755 & $04-8$ & & Upper Valanginian-Lower Barremian \\
\hline 542097 & 4617526 & $04-11$ & Kapanbogazi & Santonian \\
\hline 542097 & 4617526 & 04-12 & Caglayan & Hauterivian \\
\hline 542097 & 4617526 & $04-13$ & Caglayan & Hauterivian \\
\hline 542097 & 4617526 & $04-15$ & Kapanbogazi & Santonian \\
\hline 542097 & 4617526 & 04-16 & Kapanbogazi & Santonian \\
\hline 542158 & 4617960 & 04-19 & Caglayan & Barremian \\
\hline 593438 & 4647043 & $04-20$ & Akveren-Atbasi & Upper Maastrichtian \\
\hline 595432 & 4646305 & $04-21$ & Akveren-Atbasi-Kusuri & Lower Eocene NP13 \\
\hline 669099 & 4630111 & $04-22$ & Akveren-Atbasi & Upper Palaeocene NP9 \\
\hline
\end{tabular}




\begin{tabular}{|c|c|c|c|c|}
\hline 653700 & 4609944 & $04-23$ & Caglayan & Berriasian-Valanginian \\
\hline 675286 & 4587100 & $04-24$ & Kusuri & Lower Eocene NP13 \\
\hline 658851 & 4594733 & $04-25$ & Kusuri & Middle Eocene NP14 \\
\hline 646635 & 4597624 & $04-26$ & Kusuri & Lower Eocene NP13 \\
\hline 373427 & 4570281 & $04-29 A B$ & Yemisliçay, Kale & Santonian \\
\hline 374757 & 4569983 & $04-30$ & Yemislisçay, Sarikorkmaz & Santonian \\
\hline 378272 & 4574985 & $04-31$ & Yemisliçay, Red Pellagic L. & Late Cretaceous \\
\hline 389917 & 4584302 & $04-32$ & Inalti & Lower Cretaceous \\
\hline 390201 & 4585136 & $04-33$ & Caglayan, Kilimli-Inpiri & Lower Cretaceous \\
\hline 443577 & 4607278 & $04-36$ & Kusuri & Middle Eocene \\
\hline 452624 & 4621116 & $04-41$ & Caglayan & Lower Aptian \\
\hline 452624 & 4621116 & $04-42 \mathrm{AB}$ & Cemaller & Santonian \\
\hline 453044 & 4620737 & $04-45$ & Caglayan & Barremian \\
\hline 443147 & 4609861 & $04-46$ & Akveren, Alapli & Upper Campanian \\
\hline 435284 & 4563157 & $04-47$ & Akveren-Atbasi & Upper Paleocene NP9 \\
\hline 445964 & 4561524 & $04-51$ & Caglayan, Ulus & Barremian \\
\hline 450541 & 4561488 & $04-53$ & Inalti & Early Cretaceous \\
\hline 460527 & 4555717 & $04-55$ & Caglayan, Ulus & Early Cretaceous \\
\hline 462152 & 4556461 & $04-56$ & Kusuri & Middle Eocene \\
\hline 471258 & 4563317 & $04-58$ & Kusuri & Lower Eocene NP13 \\
\hline 480964 & 4563642 & $04-59$ & Kusuri & Lower Eocene NP13 \\
\hline 523991 & 4564113 & $04-60$ & Kusuri & Lower Eocene NP13 \\
\hline 563169 & 4579102 & $04-61$ & Kusuri & Lower Eocene NP12 \\
\hline 564605 & 4574754 & $04-62$ & Kusuri & Middle Eocene \\
\hline 559672 & 4609981 & $04-65$ & Kusuri & Lower Eocene NP12 \\
\hline 555747 & 4610851 & $04-66$ & Kusuri & Middle Eocene NP14 \\
\hline 542097 & 4617526 & $04-69$ & Kapanbogazi & Santonian \\
\hline 551523 & 4611032 & $04-70$ & Kusuri & Lower Eocene NP12 \\
\hline 551523 & 4611032 & 04-70A & Kusuri & Lower Eocene NP13 \\
\hline 551523 & 4611032 & 04-70C & Kusuri & Lower Eocene NP13 \\
\hline 378854 & 4575113 & $06-2$ & Yemisliçay, Red Pellagic L. & Late Cretaceous \\
\hline 391811 & 4585492 & $06-4-8$ & Caglayan, Kilimli-Inpiri & Barremian \\
\hline 392563 & 4582373 & $06-11$ & Caglayan, Tasmaca & Upper Aptian \\
\hline
\end{tabular}




\begin{tabular}{|c|c|c|c|c|}
\hline 392734 & 4582133 & $06-12$ & Caglayan, Tasmaca & Upper Aptian \\
\hline 390750 & 4580399 & $06-13$ & Caglayan, Cemaller & Upper Albian \\
\hline 390327 & 4580791 & $06-14$ & Caglayan, Cemaller & Early Cretaceous \\
\hline 389590 & 4581575 & $06-15$ & Caglayan, Velibey & Azoic \\
\hline 410187 & 4558194 & $06-17$ & Atbasi & Uppermost Palaeocene NP9 \\
\hline 409612 & 4557625 & $06-19$ & Atbasi & Lower Palaeocene NP3 \\
\hline 409553 & 4557439 & $06-18,20$ & Atbasi & Upper Palaeocene NP5 \\
\hline 409519 & 4557956 & $06-21$ & Atbasi & Uppermost Palaeocene NP9 \\
\hline 409666 & 4559005 & $06-22$ & Atbasi & Lowermost Eocene NP10 \\
\hline 424088 & 4571398 & $06-23$ & Atbasi & Lower Eocene NP11 \\
\hline 419895 & 4576332 & $06-24$ & Kusuri & Lower Eocene NP12 \\
\hline 417958 & 4578064 & $06-25$ & Kusuri & Lower Eocene NP13 \\
\hline 411483 & 4582015 & $06-27$ & Caglayan, Tasmaca & Lower Albian \\
\hline 411483 & 4582015 & $06-28$ & Yemisliçay, Dereköy, Cambu & Late Cretaceous \\
\hline 411056 & 4583307 & $06-30$ & Caglayan, Sapça & Upper Aptian \\
\hline 411056 & 4583307 & $06-31$ & Caglayan, Sapça & Upper Aptian \\
\hline 410172 & 4584966 & $06-32$ & Caglayan, Sapça & Lower Albian \\
\hline 392539 & 4585066 & $06-33$ & Caglayan, Velibey & Azoic \\
\hline 392523 & 4582627 & $06-34$ & Caglayan, Velibey & Azoic \\
\hline 393694 & 4581731 & $06-35$ & Caglayan, Tasmaca & Lower Albian \\
\hline 394184 & 4581736 & $06-36$ & Caglayan, Tasmaca & Lower Albian \\
\hline 392268 & 4581087 & $06-38$ & Caglayan, Cemaller & Upper Albian \\
\hline 391715 & 4581112 & 06-39 & Caglayan, Cemaller & Upper Albian \\
\hline 452010 & 4620905 & $06-40$ & Caglayan & Upper Aptian \\
\hline 452010 & 4620905 & $06-41$ & Cemaller & Coniacian-Santonian \\
\hline 452427 & 4620910 & $06-42$ & Kapanbogazi & Santonian \\
\hline 452613 & 4621066 & $06-43,44$ & Caglayan & Barremian \\
\hline 452568 & 4621172 & $06-45$ & Caglayan & Barremian \\
\hline 453579 & 4620743 & $06-49-51$ & Caglayan & Barremian \\
\hline 453500 & 4618943 & $06-52$ & Caglayan & Upper Aptian \\
\hline 454874 & 4621982 & $06-57$ & Caglayan & Upper Aptian \\
\hline 454731 & 4621724 & $06-58$ & Caglayan & Upper Aptian \\
\hline 446318 & 4614856 & $06-59$ & Akveren, Alapli & Lower Campanian \\
\hline
\end{tabular}




\begin{tabular}{|c|c|c|c|c|}
\hline 446544 & 4614643 & $06-60$ & Akveren, Alapli & Lower Campanian \\
\hline 443132 & 4609951 & $06-61$ & Akveren, Alapli & Upper Campanian \\
\hline 430130 & 4595224 & $06-62$ & Kusuri & Middle Eocene NP14b \\
\hline 419134 & 4602847 & $06-63$ & Yemisliçay, Unaz & Santonian \\
\hline 404250 & 4594100 & $06-64$ & Caglayan, Kilimli-Inpiri & Upper Aptian \\
\hline 404075 & 4594084 & $06-66$ & Caglayan, Kilimli-Inpiri & Upper Aptian \\
\hline 403348 & 4594134 & $06-67$ & Caglayan, Kilimli & Aptian \\
\hline 400957 & 4592334 & $06-68$ & Caglayan, Kilimli & Lower Aptian \\
\hline 401409 & 4592715 & $06-72$ & Caglayan, Kilimli-Inpiri & Lower Aptian \\
\hline 402512 & 4593636 & $06-73$ & Caglayan, Kilimli-Inpiri & Lower Aptian \\
\hline 405098 & 4587045 & $06-74$ & Caglayan, Velibey & Azoic \\
\hline 408407 & 4586323 & $06-75$ & Caglayan, Sapça & Upper Aptian \\
\hline 408014 & 4584886 & $06-76$ & Caglayan, Sapça & Upper Aptian \\
\hline 410755 & 4585914 & $06-77$ & Caglayan, Sapça & Upper Aptian \\
\hline 412041 & 4586200 & $06-78$ & Caglayan, Sapça & Lower Aptian \\
\hline 412210 & 4586567 & $06-79-81$ & Caglayan, Sapça & Lower Aptian \\
\hline 447811 & 4606314 & $06-82$ & Kusuri & Middle Eocene NP15 \\
\hline 447937 & 4605242 & $06-83$ & Kusuri & Upper Eocene NP19-20 \\
\hline 454929 & 4598996 & $06-84$ & Akveren-Atbasi & Upper Santonian-Lower Campanian \\
\hline 459896 & 4596892 & $06-86$ & Caglayan, Ulus & Aptian \\
\hline 466436 & 4598877 & $06-87$ & Caglayan, Ulus & Aptian \\
\hline 468909 & 4602930 & $06-88$ & Caglayan, Ulus & Aptian \\
\hline 471798 & 4607246 & 06-89 & Caglayan, Ulus & Aptian \\
\hline 471947 & 4608846 & $06-90$ & Caglayan, Ulus & Upper Aptian \\
\hline 472331 & 4609988 & 06-91 & Caglayan, Ulus & Upper Aptian \\
\hline 469483 & 4608745 & $06-92-95$ & Caglayan, Ulus & Upper Aptian \\
\hline 473794 & 4604309 & $06-96-97$ & Caglayan, Ulus & Aptian \\
\hline 478087 & 4608282 & $06-98$ & Caglayan, Ulus & Barremian \\
\hline 483322 & 4608514 & 06-99 & Caglayan, Ulus & Barremian \\
\hline 487851 & 4611048 & $06-100$ & Caglayan, Ulus & Barremian \\
\hline 495665 & 4612761 & 06-101-105 & Caglayan, Ulus & Barremian \\
\hline 478790 & 4586589 & 06-106 & Caglayan, Ulus & Upper Aptian \\
\hline 476576 & 4584049 & $06-107$ & Caglayan, Ulus & Upper Aptian \\
\hline
\end{tabular}




$\begin{array}{lllll}474867 & 4578606 & 06-108 & \text { Caglayan, Ulus } & \text { Upper Aptian } \\ 468740 & 4569277 & 06-109 & \text { Caglayan, Ulus } & \text { Lower Cretaceous } \\ 467866 & 4564677 & 06-114 & \text { Caglayan, Ulus } & \text { Upper Aptian } \\ 483687 & 4544118 & 06-121 & \text { Kusuri } & \text { Lower Eocene NP12 } \\ 488495 & 4544328 & 06-122 & \text { Kusuri } & \text { Middle Eocene NP16-17 } \\ 490515 & 4544543 & 06-124 & \text { Kusuri } & \text { Eocene } \\ 490515 & 4544543 & 06-125 & \text { Kusuri } & \text { Middle Eocene NP17 } \\ 613771 & 4608680 & 06-126 & \text { Atbasi } & \text { Uppermost Maastrichtian } \\ 614080 & 4608670 & 06-127 & \text { Atbasi } & \text { Upper Paleocene NP9 } \\ 613865 & 4607737 & 06-129 & \text { Palaeocene-Eocene } & \text { Middle Eocene NP14b } \\ 628232 & 4609604 & 06-133 & \text { Atbasi } & \text { Uppermost Maastrichtian } \\ 628232 & 4609604 & 06-134 & \text { Atbasi } & \text { Lower Eocene NP13 }\end{array}$

Table 1: Coordinates and ages of the 164 samples dated with nannoplankton.

\begin{tabular}{|c|c|l|}
\hline Stage & $\begin{array}{c}\text { Nannoplankton } \\
\text { zone }\end{array}$ & \multicolumn{1}{|c|}{ Nannofossils assemblages } \\
\hline Upper Eocene & NP 19- NP 20 & $\begin{array}{l}\text { Chiasmolithus oamaruensis, Cycloccolithus } \\
\text { formosus Dictyococcites dictyodus, } \\
\text { Discoaster barbadiensis, Ericsqonia } \\
\text { subdisticha, Isthmolithus recurvus, } \\
\text { Reticulofenestra umbilica }\end{array}$ \\
\hline & NP17 & $\begin{array}{l}\text { Cribrocentrum reticulatum, Cyclococcolithus } \\
\text { formosus, Dictyococcites dictyodus, } \\
\text { Discoaster barbadiensis, D. saipanensis, D. } \\
\text { tani nodifer, Reticulofenestra umbilica, } \\
\text { Sphenolithus radians, Zygrhablithus } \\
\text { bijugatus }\end{array}$ \\
\hline Middle Eocene & NP 15 & $\begin{array}{l}\text { Chiasmolithus gigas, C. grandis, C. solithus, } \\
\text { Discoaster barbasiesis, Reticulofenestra cf. } \\
\text { umbilica (small), Rhabdosphaera gladius, } \\
\text { Sphenolithus furcatolithoides, S. } \\
\text { pseudoradians, Zygrhablithus bijugatus }\end{array}$ \\
\hline
\end{tabular}




\begin{tabular}{|c|c|c|}
\hline & NP 14b & $\begin{array}{l}\text { Chiasmolithus grandis, C. solitus, } \\
\text { Cyclococcolithus formosus, Discoaster } \\
\text { barbadiensis, D. sublodoensis, } \\
\text { Reticulofenestra cf. umbilica (small), } \\
\text { Rhabdosphaera inflata, Sphenolithus } \\
\text { radians, Zyghrablithus bijugatus }\end{array}$ \\
\hline & NP 13 & $\begin{array}{l}\text { same assemblage as in zone NP } 12 \text { but } \\
\text { without Mathasterites tribraciatus }\end{array}$ \\
\hline Lower Eocene & NP 12 & $\begin{array}{l}\text { Campylosphaera dela,Chiasmolithus solitus, } \\
\text { Cyclococclithus gammation, C.formosus, } \\
\text { Discoaster barbadiensis, D. binodosus, D. } \\
\text { lodoensis, Discoasteriodes kuepperi, } \\
\text { Marthasterites tribrachiatus, Sphenolithus } \\
\text { radians }\end{array}$ \\
\hline & NP 10 & $\begin{array}{l}\text { Discoaster binodusus, D.multiradiatus, } \\
\text { Marthasterites contortus }\end{array}$ \\
\hline Upper Paleocene & NP 9 & $\begin{array}{l}\text { Coccolithus pelagicus, Discoaster } \\
\text { gemmeus, D. multiradiatus, Ellipsolithus } \\
\text { macellus, Ericsonia subpertusa, } \\
\text { Fasciculithus tympaniformis, Sphenolithus } \\
\text { anarophus, Toweius eminens }\end{array}$ \\
\hline & NP 5 & $\begin{array}{l}\text { Ellipsolithus macellus, Ericsonia subpertusa, } \\
\text { Fasciculithus tympaniformis }\end{array}$ \\
\hline Lower Paleocene & NP 3 & $\begin{array}{l}\text { Chiasmolithus danicus, Coccolithus } \\
\text { pelagicus, Cruciplacolithus tenuis, Ericsonia } \\
\text { subpertusa, Zygodiscus sigmoides }\end{array}$ \\
\hline $\begin{array}{c}\text { Upper } \\
\text { Maastrichtian }\end{array}$ & & $\begin{array}{l}\text { Arkhangelskiella cymbiformis, } \\
\text { Ceratolithoides aculeus, Cribrosphaera } \\
\text { ehrenbergii, Eiffellithus turriseiffeli, } \\
\text { Lithraphidites quadratus, Microrhabdulus } \\
\text { decoratus, Micula murus, M. staurophora, } \\
\text { Prediscosphaera cretacea, within the latest } \\
\text { Maastrichtian occurrence of Micula prinsii }\end{array}$ \\
\hline Upper Campanian & & $\begin{array}{l}\text { Broinsonia parca, Ceratolithoides aculeus, } \\
\text { Cribrosphaera ehrenbergii, Eiffellithus } \\
\text { eximius, E. turriseiffeli, Lucianorhabdus } \\
\text { cayeuxii, Prediscosphaera cretacea, } \\
\text { Reinhardtites anthphorus, Quadrum } \\
\text { gothicum, Q. trifidum }\end{array}$ \\
\hline Lower Campanian & & $\begin{array}{l}\text { same assemblage as within the Upper } \\
\text { Campanian but without Quadrum gothicum } \\
\text { and Q. tifidum }\end{array}$ \\
\hline
\end{tabular}




\begin{tabular}{|c|c|}
\hline Santonian & $\begin{array}{l}\text { Eiffellithus eximius, E. turriseiffeli, } \\
\text { Lucianorhabdus cayeuxii, Marthasterites } \\
\text { furcatus, Micula staurophora, } \\
\text { Prediscosphara cretacea, Reinhardtites } \\
\text { anthophorus, within the uppermost part } \\
\text { occurrence of Broinsonia parca expansa }\end{array}$ \\
\hline Coniacian & $\begin{array}{l}\text { same assemblage as in the Santonia but } \\
\text { without Reinhardtites anthophorus }\end{array}$ \\
\hline Upper Albian & $\begin{array}{l}\text { Eiffellithus turriseiffeli, Eprolithus floralis, } \\
\text { Hayesites albiensis, Parhabdolithus } \\
\text { angustus, P.embergeri, Prediscosphaera } \\
\text { cretacea, Tranolithus orionatus, Zygodiscus } \\
\text { diplogrammus, Watznaueria barnesae }\end{array}$ \\
\hline Lower Albian & $\begin{array}{l}\text { Ellipsagelosphaera communis, Eprolithus } \\
\text { floridanus, Parhabdolithus angustus, } P \text {. } \\
\text { infinitus, P. embergeri, Prediscosphaera } \\
\text { cretacea, Vagalapilla matalosa }\end{array}$ \\
\hline Upper Aptian & $\begin{array}{l}\text { Chiastozygus litterarius, Coronolithoin } \\
\text { achylosus, Ellipsagelosphaera communis, } \\
\text { Eprolithus floralis, Nannoconus bucheri, } \\
\text { N.circularis, N.elongatus, N. quadriangulus } \\
\text { apertus, N. quadriangulus quadriangulus, } \\
\text { Parhabdolithus angustus, Rucinolithus } \\
\text { irregularis }\end{array}$ \\
\hline Barremian & $\begin{array}{l}\text { Calcicalathina oblongata, Cruciellipsis } \\
\text { chiastia, Cyclagelosphaera margerelii, } \\
\text { Micrantolithus obtusus, Nannoconus colomii, } \\
\text { N.globulus, N.kamptneri, N.steinmannii, N. } \\
\text { wassalii, Parhabdolithus asper, Watznaueria } \\
\text { barnesae }\end{array}$ \\
\hline Hauterivian & $\begin{array}{l}\text { Bipodorhabdus colligatus, Bipodorhabdus } \\
\text { colligatus, Calcicalathina oblogata, } \\
\text { Cruciellipsis cuvillieri, Cyclagelosphaera } \\
\text { margerellii, Ellipsagelosphaera communis, } \\
\text { Lithraphidites bollii, Watznaueria barnesae }\end{array}$ \\
\hline $\begin{array}{l}\text { Berriasian- } \\
\text { Valanginian }\end{array}$ & $\begin{array}{l}\text { Cyclagelosphaera deflandrei, C.margerelii, } \\
\text { Ellipsagelosphaera communis, Nannoconus } \\
\text { colomii, Parhbdolithus embergeri, } \\
\text { Runcinolithus wisei, Watznaueria barnesae }\end{array}$ \\
\hline
\end{tabular}

Table 2: Nannofossil assemblages recognized for each age determination of table 1. 